\title{
Innovations in Acheulean Biface production at la Noira (France) during Middle Pleistocene in Western Europe
}

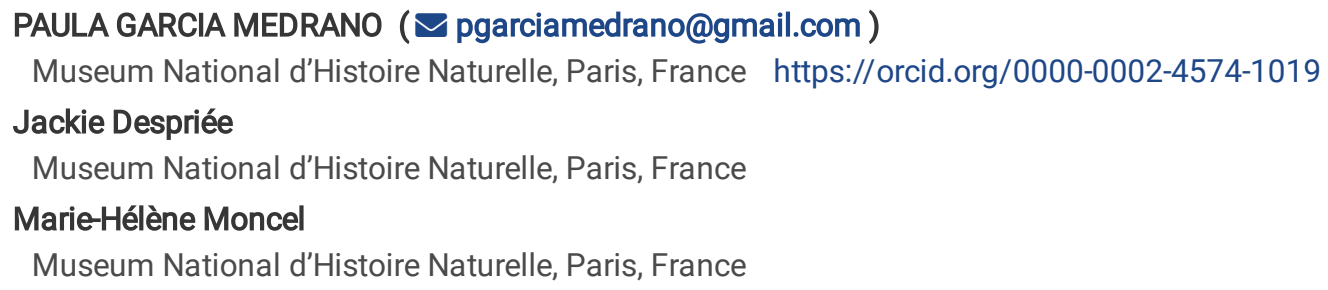

\section{Research Article}

Keywords: Acheulean, technology, geometric morphometrics, handaxes, shaping strategies

Posted Date: August 11th, 2021

DOI: https://doi.org/10.21203/rs.3.rs-146762/v2

License: (c) (i) This work is licensed under a Creative Commons Attribution 4.0 International License. Read Full License 


\section{Abstract}

The archaeological sequence of la Noira (Centre region, France) yielded two phases of occupation: ca $700 \mathrm{ka}$ (stratum a) and ca $450 \mathrm{ka}$ (stratum c). No site between these two dates has yet been discovered in the area, and this chronological period has thus been interpreted as a gap in settlement from MIS 16 to MIS 12, two crucial phases of occupation in Western Europe, before and after the long glacial event MIS 12 which record the onset of the Acheulean in Europe and earliest evidence of innovations from MIS 12 considered as a shift in human evolution. Here, we compare these two levels and track technological innovations during this time, combining technological analysis with geometric morphometrics with the use of 3D models comparison of the Large Cutting Tools (LCTs). Stratum a yielded an Early Acheulean, one of the few evidence in Europe presents tools with mainly short shaping sequences on local millstone slabs, with special attention to tips, but with clear management of tool volume. Stratum c, dated to the MIS 11, differs in that both local millstone and flints from distant sources show longer shaping sequences, the use of soft hammers for several series of removals on tools, combined with final regularizing retouch on entire edges. The morphometric approach shows a morphological transition from oval to teardrop shapes for the thinnest tools. Our data suggest a clear technological filiation between strata a and $\mathrm{c}$ and in la Noira populations from MIS 16 and MIS 12, as suggested for innovations of core technologies and land-use patterns, and raise question on local human behavioral evolution over the Middle Pleistocene in Western Europe.

\section{Introduction}

At the end of the Middle Pleistocene Transition (MPT) in Western Europe, after the Brunhes-Matuyama reversal (780 ka), climatic cycles changed, leading to significant variations in resources. These cycles must have affected the extinction/relocation of small groups of hominins, and subsequent recolonisations, between the two long MIS 16 and MIS 12 cold events (Manzi, 2004; Clark et al. 2010; Muttoni et al. 2010; Almogi-Labin 2011; Rodríguez et al. 2011; MacDonald et al. 2012; Cuenca-Bescós et al. 2011; Bar-Yosef and Belmaker 2011; Pereira et al. 2015; Carrión and Walker 2019). MIS 12 was followed by a long interglacial stage (MIS 11) which marks the beginning of new behaviours and the advent of the Neanderthal technical world (Moncel et al. 2020a). After the MIS 12 glaciation, considered as a major crisis for hominins, archaeological records show a high quantity and variety of occupations, new subsistence behaviours and technical innovations (e.g., Levallois technology, increase in light-duty tools and use of fire), and evidence of an early regionalization of traditions (Moncel et al. 2016, 2020a, 2021; Rodríguez-Hidalgo et al. 2017). Recent data suggest that some technological innovations could be rooted in the past suggesting local evolution (Moncel et al. 2021a) These behavioural changes suggest increased cognition with new skills and social interactions among European populations (Moncel et al. 2015, 2018a, b, Peretto et al. 2016).

Among other kinds of behavioural innovations, the Acheulean has been traditionally defined by the emergence of a new tool with bifacial management of volume: the handaxe (Roche, 2005; Gowlett 2006), which has been considered as evidence of new skills and changes in human cognition (Wynn 2002; Stout 2011). Due to the effectiveness and the versatility of this type of instrument, handaxes persisted for more than $1 \mathrm{Ma}$ over a vast geographical area (Moncel et al. 2018c). This tool first appeared in East Africa around $1.75 \mathrm{Ma}$, but is not present in Western Europe before 900 ka and especially from 700 ka onwards. In spite of apparent technological stability, this kind of instrument encompasses huge variability in terms of production, as well as in terms of the morphological outcome of shaping processes. Strata a and c of the la Noira site, located in the centre of France, and the large corpus of handaxes are appropriate case studies for tracking technological behaviours common to both levels and identifying innovations over time. We aim to discuss two crucial phases of hominin settlement in Western Europe but also to contribute to hypotheses positing either a filiation between European populations over time or arrivals of new populations introducing new skills after MIS 12. Renfrew (1978) distinguished between innovation and invention (Renfrew 1978), whereby the latter is the creative act that is usually invisible in the archaeological record, whereas innovation is the longterm establishment of the creative act. Sudden innovation normally indicates external introduction, while smaller increments of change suggest internal implementation through technological development, cognitive evolution or acculturation (Moncel et al. 2021). Common features between the two phases of occupation and existence of innovations rooted in the past would point to a possible filiation over time of populations between the MIS 16 and MIS 12 glacial periods and would imply that these populations were able to return to abandoned areas when the climate was favourable, aided perhaps by more complex behaviours due to internal evolution and increase of skills (Schreve 2015).

There are significant differences in terms of research tradition that hinder any comparative study. Indeed, the research in Great Britain generally used the typology of Wymer (1968), the morphometry of Roe (1968) and the reduction sequences of Newcomer (1971) and Wenban-Smith (1989). Over the same period, French researchers adopted the typology developed by Bordes (1961), which was largely replaced by the more complex concept of the "chaîne opératoire" (1990). "Chaîne opératoire" was also used in Spain, together with the Logical Analytic System (1995). The different criteria used for analying and categorising the results have made it almost impossible to compare data from the different countries. Until now, there were only partial comparisons between the major sites in Western Europe 
(Moncel et al. 2015, Nicoud et al. 2013a, b). By this reason, it was necessary to develop an unified and simple system of analyzis in order to describe and quantify critical features in lithic assemblages, exceeding the local particularities and reaching a regional interpretation of the Middle Pleistocene hominin occupation of Western Europe (García-Medrano et al. 2020).

In recent decades, new dating and excavations have been conducted to identify gaps in human occupations in Western Europe (Moncel et al. 2020a). The Centre region of France is one of the areas where two gaps have been documented, one between $1 \mathrm{Ma}$ and $700 \mathrm{ka}$ and a second one between 700 and $450 \mathrm{ka}$ (Despriée et al. 2011), possibly explained by climatic factors due to the location of the area beyond the $45^{\text {th }}$ parallel. In Western Europe, few sites can be used to investigate such gaps in human occupation. La Noira is one such example (Moncel et al. 2013, 2020a). The technological analysis of all the lithic material from stratum a at la Noira has already enabled us to explore (Moncel et al. 2013, 2016, 2020a) the onset of the Acheulean at $700 \mathrm{ka}$ in Western Europe and the technological skills of these hominins. A specific morphometric analysis of handaxe symmetry in strata a and c (lovita et al. 2017) has shown that human groups mastered tool symmetry from 700 ka onwards, despite lower shaping intensity at that time. In order to continue to track the technological drift between ca 700 and ca 450 ka, we applied the WEAP method (García-Medrano et al. 2020) on the whole corpus of handaxes of this site (García-Medrano 2020), combining for the first time a technological analysis with a broader morphometric approach using AGMT3-D software (Herzlinger and Grosman 2018; Herzlinger and Goren-Inbar 2020).

\section{The Archaeological Site Of La Noira}

The site of la Noira is located in the Middle Loire Basin (Centre region, France), on the western slope of the Cher River Valley (Desprieée et al. 2012) (Fig. 1) La Noira belongs to the very little group of sites yielding earliest evidence on the early presence of Acheulean from 700 ka (stratum a) in Western Europe. In the European context, Notarchirico (Italy) and Moulin Quignon (France) are only the two other sites with the same record and their distribution both in the North-West and South allows discussing mode of dispersal of these early Acheulean groups and abilities to occupy areas under various climates. Five successive sediments strata can be observed at the site (from bottom to top): a coarse slope deposit (stratum a with Early European Acheulean), covered by two sequences of sandy alluvial layers (stratum b), diamictons of pebbles with frost shattered debris and coarse colluvia (stratum c) and the a washed sandy-silty soil (stratum d). This paper focuses on the oldest archaeological level (henceforth referred to as the 'lower level'), located in stratum a, while the younger upper level is located at the top of stratum c.

The lower layer (stratum a) was deposited on the limestone bedrock at the beginning of a glacial stage after river incision. The slope deposits contained local lacustrine millstone slabs, some of which were selected by hominins for knapping and shaping. Occupations were located on the river bank. The age of fluvial formation was determined using the ESR method applied to optically bleached sedimentary quartz grains. The mean ESR age value obtained for the sandy formations of stratum $b$ is $655 \pm 55 \mathrm{ka}$. Tests with cosmogenic nuclide dating provide a similar value of $730 \pm 210 \mathrm{ka}$, but with an excessively high margin of error (Shen et al. 2012). The average age of the human occupation is thus around $700 \mathrm{ka}$ (39). The hominin occupation occurred between the end of river incision and the fluvial deposits, suggesting that hominins were present during the beginning of the MIS 16 glacial stage, just before the pleniglacial fluvial depositions. They left the area during the early glacial MIS 16 at around 670-650 ka, when cold conditions became too rigorous (Moncel et al. 2013, 2020a).

The petrographic composition of the sediments of stratum c (composed of three sub-levels) is identical to that of the lower stratum a, composed of sands and quartz gravels with endogenous pebbles (granite and quartz) and sedimentary siliceous rocks. The ESR date of $449 \pm 45 \mathrm{ka}$ indicates that diamicrons of stratum c could have been deposited at the end of the MIS 12 glacial (frozen cracks soil and frost debris) and mainly during the MIS 11 interglacial (eroded soil and deep channels). The remarkable preservation of the artefacts could indicate that they were not affected by frost as they were overlain by thick colluvial deposits (Dépont 1984; Despriée et al. 2017a, b; lovita et al. 2017). While local millstone was the only raw material used during the early occupations, the stratum c assemblage is composed of $30 \%$ of flint and silicifications transported from long-distance Jurassic and Cretaceous outcrops, between 50 and $100 \mathrm{~km}$ from the site (Despriée et al. 2017c).

Taphnomical and post-depositional approaches on the stratum a (Despriée et al. 2016) indicate low energy context for covering the archaeological layer and few disturbance of the material. Spatial distribution also indicates that large artefacts (tools and broken slabs) have moved on the site due to hominin activities and reveals spots of activities on a $100 \mathrm{~m}^{2}$ excavated areas. For the stratum c, geological studies indicate recurrent occupations along channels (Moncel et al. 2021b). Most of pieces show fresh edges without traces of crushing or micro-denticulations indicating any displacement due to natural post-depositional processes. Some broken slabs were found joined at stratum a (Despriée et al. 2016). Only chemical superficial processes were observed on the tool surfaces. The two phases yield large lithic assemblages with complete debitage reduction processes, from selection of raw materials to flaking and shaping processes and retouches 
(Table 1) (Moncel et al. 2021b). While hominins selected only in situ material for the 700 ka stratum a, the occupations of stratum c indicate changes in land-use patterns, with introduction of stones from a perimeter of 50-100 km around. Analyzes of residus and use-wear traces on the lithic material on stratum a indicate various domestic activities (Hardy et al. 2018) suggesting that the site was not only workshops. La Noira is thus a key-site to question the process of innovations, in particular on the Large Cutting Tools in Western Europe from MIS 16 to MIS 11 and in an area located on this mid-part of Europe considered as less favourable than the South.

\section{Materials And Methods}

The analysis of the whole sample of the 78 handaxes and cleaver-like tools from stratum a and stratum c of la Noira were done through a detailed technological and morphometric study aiming to analyse final tool variability. The applied WEAP method was developed in the context of a Marie Skłodowska Curie IF-EF-ST Fellowship (IP: 748316). It is an unified method of analysis, drawing together a selection of criteria considered significant from previous research methodologies applied to the Western Acheulean record, including typological, technological and processual issues, together with new proposals on morphometrics (García-Medrano et al. 2020). As we have briefly explored, different systems of analysis applied in different countries have made it almost impossible to properly compare the data from different sites, their being only occasional comparisons between the main Acheulean assemblages in Western Europe (e.g. Moncel et al. 2015; Moncel et al. 2018c). WEAP's method is based on three main premises: 1) standardizing and simplifying terminology; 2 ) avoiding the classification of tools before analysis; 3 ) analysing each tool in two different ways: a) As a single unit, including aspects such as raw material type, blank type, facial shaping, cortex presence, edge delineation, profile symmetry, number of scars); b) as the sum of the different parts, each of which are analysed independently, defining the type of hammer used, number of removal series, depth of scars on edges, invasiveness of each removal series, and type of shaping (Table 2). Combining all these features, a Multivariate Analysis (PCA) identifies the differences and similarities of LCTs from both levels, comparing raw materials and types of blank. A detailed description of the Method is recorded in the Part 1 of the Supplementary Information.

As a single unit, a LCT could be defined by a combination of features that make it unique: raw material and blank type, facial working, edge delineation, bifacial and bilateral symmetry and number of scars. The division of each tool into three parts is based on the metrical distinction of distal part at 1/5 in length and the proximal part, at 4/5 in length (Roe 1968). Therefore, each technological analysis is undertaken three times. The technological features considered are type of hammer, number of removal series, depth of scars on edge, invasiveness of scars on tool's surface, type of shaping and any patina variation (all details recorded in SI Part 1).

Together with the technological descriptions, measurements were the basis of his handaxe morphological types (triangulaires, subtriangulaires, cordiformes, discoid, ovate and limandes) according to three main criteria: length against width, thickness against width, and Bordes' edge shape (Bordes 1961). However, the boundaries between the categories were sometimes not fully precise, as intermediate shapes exist. Roe (1968) included three new measures: distal width (B1), proximal width (B2) and distal thickness (T1), to distinguish three shapes: pointed, oval and cleaver-type tools. For our method, we retain all these measures to describe the tools (SI Table 1), and compare the results with the morphological and technical features such as reduction intensity. The measurements have also been used to produce ratios to enhance handaxe description (Roe 1968; 1994; Bordes 1961). Elongation is given as length/width with values > 1.5 described as elongated. Refinement is measured by width/thickness with refined handaxes having values $>2.35$. In addition to the basic measurements and ratios, we have measured six angles along one edge (the most continuous and regular one) according to the division of these tools in five parts: A1 (midpoint of tip), A2 (1/5 of the length), A3 (2/5), A4 (3/5), A5 (4/5) and A6 (midpoint of butt). Where there is cortex, the angle has not been recorded.

To complete the technological analysis, we also applied the Geometric Morphometric analysis to describe tool shape with 3D models. All the tools were scanned using a laser scan (DLP projector) and Flexscan software (LMI technologies), transferred from the Fragmented Heritage Project (University of Bradford). All models are available for scientific and academic purposes at ZENODO (García-Medrano et al. 2020). The 3D models were processed using the AGMT3-D software (Herzlinger and Grosman 2018; Herzlinger and Goren-Inbar 2020). This consists of a data-acquisition procedure for automatically positioning 3D models in space and fitting them with grids of 3D semilandmarks. In fact, each point of the grid consists of two semi-landmarks, one placed on each face of the artefact, so that a $50 \times 50$ grid provides 5,000 landmarks (Fig. 2A). The top and bottom latitudes capture the exact 3D outline of the artefact's distal and proximal ends. Therefore, this protocol provides a list of landmarks that accurately express the artefact's volumetric configuration. It also provides a number of analytical tools and procedures that enable data processing and statistical analysis (Herzlinger and Goren-Inbar 2020). For this paper, data obtained with 3D models are presented.

The multivariate outline data were projected into two dimensions so that the underlying shape variables could be qualitatively examined and compared. In order to interpret the Principal Component Analysis (PCA) results from a morphological perspective, Procrustes 
superimposed shape data were examined using thin-plate splines to facilitate the visualization of shape changes from the group mean along relative warp (i.e., principal component) axes (Hammer and Harper, 2006; Costa 2010). By examining the morphological deformations and XY plots of specimens from the PCA scatters, it was possible to interpret shape variation by itself, without the size effect, and compare the different tools within a site or between different sites. In addition, the derived principal component scores also allowed for the application of other quantitative tests of multivariate equality of means between the groups (Herzlinger and Grosman 2018; Herzlinger and Goren-Inbar 2020).

The latest version of this software also offers different quantitative approaches to the analysis of specific variations in shape. Firstly, we will use the surface analysis $\left(\mathrm{in}^{2}\right)$ and volume $\left(\mathrm{in}^{3}\right)$ data apply a quantitative approach to reduction intensity. The Scar Density Index (SDI, Clarkson, 2013; Shipton and Clarkson, 2015a, b) has been defined as the number of flake scars (greater than $10 \mathrm{~mm}$ in maximum dimension) divided by the surface area. As García-Medrano and colleagues noted (2019), a loss of information during the knapping process, contrasting this value with volume information, could establish a useful relationship between the number of scars and tool size. Lastly, the landmark data were used to calculate the degree of deviation from perfect bilateral (Fig. 2B) and bifacial symmetries (Fig. 2C), as well as the edge section regularity (Fig. 2D) of each item in the sample (51). For bilateral symmetry, this was conducted by measuring the mean 3D Euclidean distance between a mirror reflection of the landmarks placed on one lateral half of each object and the corresponding landmarks on the other half. The same procedure was performed for bifacial symmetry, but on the two opposing faces. In a perfect bilaterally or bifacially symmetrical object, the value of these indices will be 0 , with increasing values indicating less symmetrical objects.

\section{Results}

The studied corpus is composed of 31 handaxes for stratum a and 47 handaxes and cleaver-like tools (bifacial tool with a round or transverse extremity) for stratum c. They were collected in situ, and come from recent excavations and systematic surveys carried out for the three last decades in the quarry. All the handaxes from the lower level (stratum a) are made on local millstone slabs, and in nearly $65 \%$ of cases, slabs are only used for shaping. In the upper level (stratum c), our corpus of tools is shaped on comparable proportions of millstone slabs $(48.94 \%)$ and flint nodules $(51.06 \%$, Table 3$)$. For $34 \%$ of the series, it was impossible to identify the type of blank, due to invasive shaping.

The combination of the technological features (Table 2, Supplem. Inform. Tables 2-5) in a multivariate approach (Principal Component Analysis) indicates that technological differences exist between the two levels (Fig. 1). This PCA accounts for more than $66 \%$ of the variability of the series. PC1 (43.11\%) divides the samples according to level, whatever the raw material (millstone or flint) or type of blank (slab, flake or nodule).

\subsection{Stratum a}

All the handaxes are made with hard hammers (58.06\%) or with a combination of hard and soft (32.26\%) hammers, especially on tool extremities (Fig. 4). The tips appear much more worked and retouched than the cortical butts (more than $83 \%$ ). Tool edges are mainly sinuous $(48.39 \%)$ and the profile is non-symmetric (80.65\%). The high variability of the corpus is mainly due to the type of façonnage of the tips. For more than $50 \%$ of tools, we observe one or two face by face or alternate series of removals. Less than $50 \%$ bear final retouch, and retouch is absent from lateral and proximal cutting edges. Removals affect the edges either marginally (51.61\%), producing regular edges, or more intensely (48.39\%), generating more denticulate and irregular plan-shape profiles. When only one series of removal exists, it is non-invasive over the tool surface. When there are several series of removals, shaping is more invasive, and can extend up to the midpart of the tool surface. In nearly $40 \%$ of cases, there is a combination of an invasive first series of removals and a second series along the tool edges. Butts retain $40-90 \%$ of the original cortex for more than $45 \%$ of tools. When removals are present, they are concentrated on butt edges. Finally, the corpus of Large Cutting Tools (LCTs) from stratum a presents high shaping variability with a significant difference in the management of tips and butts. Tips present more careful treatment, sometimes with final retouch while butts remain mainly cortical (Suppl. Inform., Fig. 3).

The only exception to this high variability concerns pieces on unknown blanks (13\% of tools). The PCA shows how this category of tools is clearly affected by the PC2 (23.14\%) (Supp. Inform. Fig. 4). They differ in that they are characterized by longer operative chains with two series of removals, the first one invasive and the second one short on both the tip and the upper part of the tool, followed by final retouch only on the tip. In both cases, hard and soft hammers are used. The butt is less cortical (40\%) and shaped by only one invasive series of removals by hard hammer percussion. 


\subsection{Stratum c}

The corpus from stratum c includes handaxes and some 'cleaver-like' handaxes (handaxes with wider convexity on tips, generating a sort of transverse end). The tools mainly show higher standardization with longer operative chains and significant blank reduction (Fig. 5). Shaping extensively affects the entire tools with evidence of the use of hard and soft hammers on the whole piece. The presence of cortex is limited to the butts or part of the lower surface and the tips have no cortex (89\%). $23 \%$ of tools bear no cortex. The tools present mainly non-symmetric profiles but the proportion of symmetric tools increases (up to $20 \%$ ) with rectilinear edges (54\%). The use of soft hammers (around $60 \%$ ) is clearly visible on all the sectors of the tools (tip, mid and butts). For $49 \%$, dense final retouch obliterates the last removals. For $27.66 \%$ of the tools, the tip is shaped by two series of removals, combining invasive and non-invasive scars. Final retouch can extend to the midpart of the tool surface or can be limited to the edges. Finally, for $17 \%$ of cases, we also documented a coup de tranchet removal with a non-retouched distal edge.

The midpart of tools is above all worked by two series of alternate removals $(63.87 \%)$ with final retouch and without cortex $(28 \%)$. Like in stratum a, this type of shaping profoundly modifies edges. Nevertheless, for this level, we observe a change in shaping strategies mainly for tools on millstone slabs. The edges are more regular, with a combination of a first invasive series of removals, followed by a noninvasive second series and finally, marginal retouch confined to the edges. Butts are non-cortical or with small patches of cortex. In $92 \%$ of cases, there is only one series of removals and marginal use of a soft hammer, mainly on tools shaped on flakes.

\subsection{Stratum a vs stratum c LCTs}

The Principal Component Analysis defines the existence of two clear groups of tools: strata a and c (Fig. 6). The differences are independent of the type of raw material (millstone and flint) and the type of blank used for shaping (slabs, flakes or nodules). The distance between strata a and c shows rather a technological origin, possibly related to a change in shaping strategies. The first main difference between these groups is that sequences are more diversified and shorter for stratum a tools, and longer and more standardized for stratum c tools. In addition, out of the whole set of technological features considered here, the presence of original cortex (Fig. 6A) and the different combinations of series of removals (Fig. 6B) have a major effect on the distance between these two assemblages (Suppl. Inform. Fig. 3 and Fig. 4), which is also visible by Cluster analysis (Fig. 6C). Handaxes in stratum a present cortex on $50 \%$ of tools (butt and mid parts), and sometimes covers the whole instrument. In stratum c, there is an increase in the ratio of non-cortical tools, as well as in the use of final retouch, independently of the type of blank used. PCA also points to a clear differentiation of tools from stratum a, which present longer shaping sequences and unknown or indeterminate blanks (Unknown). They are clearly apart on the PCA graph and are represented as an independent branch of the Cluster. Tools from stratum c show a different pattern, reflecting a certain association between raw material and blank type. Millstone is mainly associated with what slabs, and flint types present the same technological features as handaxes made on unknown blanks. Flakes appear as an independent group, regardless of raw materials.

The results of the geometric morphometric analyses of tools from strata a and c of la Noira indicate the extent of intra-group shape variability, expressed as the mean multidimensional Euclidean distance of all items of a group from its group centroid. Overall, the groups considered are fairly similar (Fig. 7) but tools from stratum a present higher variability. The most homogeneous group is composed of millstone tools from stratum $\mathrm{c}$. The distribution of the total standardized coefficients across the three dimensions $\mathrm{X}, \mathrm{Y}$ and $\mathrm{Z}$ shows differences in relative width, length and thickness respectively (Table 4). In the archaeological assemblages, most of the variability corresponds to differences in relative thickness, mainly in stratum $\mathrm{c}$ and specifically for millstone tools. On the other hand, the tools from stratum a show higher variability in width and length.

Figure 7 displays a PCA scatter plot of the first two PC, showing $32.50 \%$ of the entire shape variability of the whole sample, including $95 \%$ confident ellipses and centroids (corresponding to mean shapes). PC1 (22.13\%) indicates the difference between oval vs pointed shapes. PC2 (10.13\%) shows the difference between the localization of the main thickness of the tool and the convexity of the butt (mid-upper part or mid-lower part). Shape distribution is fairly homogeneous but some differences are visible. Tools from stratum a present a trend towards oval shapes, with maximum thickness located on the midpart of tools. On the other hand, tools from stratum c present a tendency towards pointed shapes, with maximum thickness on the mid-proximal part of the pieces and a significant reduction in distal width and thickness.

Geometric morphometric shape analyses quantify these differences using a single value, representing the multidimensional Euclidean distance between the means of each group. Together with the results of the Wilcoxon Rank-sum test on the inter-point distances between the means of each group and the items in the opposite group, it shows that differences between the two strata are statistically significant $(n 1=32, n 2=39$, ranksum=4128, $p=\llbracket 0.01$ ), even for the same raw material (millstone $n 1=32, n 2=18$, ranksum=2086, $p=\llbracket 0.01$ ). If we compare raw materials in stratum c (millstone and flint), differences are not significant ( $n 1=18, n 2=21$, ranksum=1454, $p=0.39)$. The same 
results are obtained applying the MANOVA test on the first 10 PC (Table 5). The greatest differences emerge from comparisons between

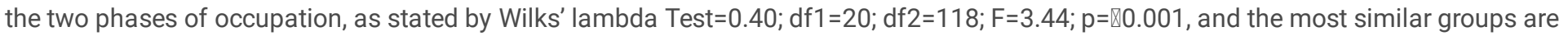
millstone and flint tools of stratum a.

Tool size and thickness decrease from stratum a to stratum c (Suppl. Inform, Table 6). Millstone and flint tools from stratum c present nearly the same values, indicating common strategies, regardless of the stones and their natural geometry. In addition, we must point out significant variation in distal vs proximal length. In stratum a, proximal length is higher, while in stratum c, distal length is higher (Fig. 8A). This is consistent with the geometric morphometric analysis and the contrast between oval shapes in stratum a, with longer bases, and more pointed shapes, with longer distal parts in stratum c.

Through the analysis of six angles measured along each edge, we document more acute angles on the mid-distal part, and wider angles on the mid-proximal part, in both strata (Figure 8B, Table 6). However, in stratum a, due to the lesser degree of edge shaping standardization, most of the angles are between $45^{\circ}$ and $80^{\circ}$ along the whole edge, and only some tips extend beyond this range. In stratum $\mathrm{c}$, where a predominant use of soft hammers is associated with longer sequences, we observe a significant change in angles. The angles of the cutting edges are more acute, homogeneous and differ between the distal and the proximal sectors of the tool. Tip angles are between $30^{\circ}$ and $45^{\circ}$, mid part edge angles between $40^{\circ}$ and $70^{\circ}$ and butt angles between $60^{\circ}$ and $80^{\circ}$.

The Scar Density Index (SDI) in relation to tool volume is coherent with the technological and morphometric analysis (Table 7). This ratio is higher for tools from stratum c, as well as for tools made on an unknown blank in stratum a. Therefore, the longer the shaping process, the higher the ratio between SDI and volume. But this also implies that the higher variability and lower standardization of the handaxes from stratum a has a clear effect on this result (Table 2). For raw materials, we can see the same pattern, between flint tools, which present the highest ratio, and millstone handaxes with the lowest ratios.

The statistical analysis of the degree of symmetry of tools shows that the main differences are between millstone handaxes from stratum a and stratum c. We note an increase in bilateral symmetry with an average of $25 \%$ (Table 8 ). Wilcoxon rank sum tests confirm that this difference is statistically significant $(n 1=32, n 2=18$, ranksum $=916, p=0.04)$. In terms of bifacial symmetry, there is an increase of nearly $35 \%$ throughout the sequence, which is statistically significant $(n 1=32, n 2=18$, ranksum $=968, p=\llbracket 0.01)$. The edge irregularity test shows that, in all cases, both edges of the same tool are always different. Nevertheless, as bilateral and bifacial symmetry show higher diversity for millstone tools from stratum a, flint tools present more regular edges. As mentioned previously, the main difference between the tools from the two strata is the combination of several series of removals (duration of shaping processes). In the case of flint, there is often a third series, and final non-invasive retouch on the cutting edges (Fig. 5D). This has a clear impact on the regularity of the edges (profile symmetry). Nevertheless, the main difference between the millstone handaxes in the two strata is the massive use of at least two series of removals on the midparts and butts of the tools from stratum c, which dramatically reduces tool thickness. Bilateral and bifacial symmetry (plan shape symmetry) is thus affected.

\section{Discussion}

The Early Pleistocene is marked by climate cycles of $41 \mathrm{ka}$, leading to temperate and more open conditions during glacial to interglacial transitions (Almogi-Labin 2011; Rodríguez, 2011; MacDonald 2012, Guthrie 1984; Ashton et al. 2011; Candy et al. 2011; Carrión et al. 2011; Messager et al. 2011; Abbate 2012; Elderfield 2012; Orain 2013). More open environments were favourable to human colonization. During the Middle Pleistocene, the shift to c.100 ka climatic cycles, designated as the Middle Pleistocene Transition (MPT) (Clark 2006; Muttoni 2010, 2018, Manzi 2004; Ashton and Lewis 2012), led to more extreme conditions which could have profoundly impacted human populations and dispersions, and may explain possible successive depopulations or extinctions of small groups of hominins during cold events in the north, necessitating re-colonization from the south during warmer events (Dennell et al. 2011). The second climatic transition (Mid-Brunhes Event-MBE) between MIS 13 and 11, with more marked glacial-interglacial cycles might explain in part the wider diffusion of the Acheulean through Western Europe during warmer interglacials and the extension of the mammoth steppe in the northwest from 500 ka (Jozuel et al. 2007; Paillard 2015). For north-western Europe, evidence suggests occasional dispersals, which would account for the diversity of strategies due to regular introductions of new behaviours and populations. Gaps are also recorded in southern Europe. At Atapuerca, for example, an occupation hiatus is observed between 800 and 500 ka (Rodríguez et al. 2011; Mosquera et al. 2013), with exception of one quartz flake from TD7 (Ollé et al. 2013), ongoing fieldwork recently added just three artefacts for unit TD8 (P.G.M., unpublished data). A recent study (Blain et al. 2021) suggest that the scarcity of forested areas could be a probable cause of this punctual presence. In fact, from a strictly paleoclimatic point of view, neither TD7 nor TD8 shows climatic envelopes that are entirely incompatible with a human presence, but TD8 presents a lower forested cover. A similar hiatus occurs in the centre of France, between $1 \mathrm{Ma}$ and 700 ka and 700 to $500 \mathrm{ka} \mathrm{(Moncel} \mathrm{et} \mathrm{al.} \mathrm{2018c).} \mathrm{La} \mathrm{Noira} \mathrm{(Center} \mathrm{of} \mathrm{France)} \mathrm{and} \mathrm{above} \mathrm{all} \mathrm{Moulin} \mathrm{Quignon} \mathrm{(Somme} \mathrm{Valley,} \mathrm{North-West} \mathrm{France)}$ 
suggest a punctual expansion of the Acheulean culture northwards the $45^{\text {th }}$ parallel, during MIS17 for la Noira and MIS 16 for Moulin Quignon. Hominins disappeared at la Noira when too cold (beginning of MIS 16) while at Moulin Quignon, they possibly occupied the area under cold or fresh conditions (Antoine 2019). At Notarchirico (Italy), in Southern Europe, recent fieldworks indicate Acheulean occupations between 610 and 695 ka during both the MIS 17 and MIS 16 under moderate climatic conditions (Moncel et al. 2020b).

In Early Acheulean African assemblages, for example, Olduvai, Bed II (1.5 Ma), Gadeb (1.7-1.5 Ma to 0.8 Ma) or Peninj (1.6-1.5 Ma), in East Africa, tools are mainly pick-like with flat or triangular cross-sections and little overall volume management. These tools are associated with minimally shaped LCTs on cobbles and flakes, unifaces and a large diversity of other types of heavy-duty tools (Leakey 1971; McPherron 2066; de laTorre et al. 2008; Semaw et al. 2018). A technological shift is then recorded at c. 1 Ma with the development of the use of soft hammers, together with a higher ratio of more standardized handaxes (Texier 2001, 2018; Roche 2005; Roche et al. 2003). Whatever the origin of Acheulean behaviours in Europe, similar technological and morphometric changes are also recorded over time in the assemblages. Stratum a of la Noira attests to the mastery of biface production, with the management of volume and tool symmetry, assisted in some cases by the use of soft hammers, mainly on distal parts (Moncel et al. 2020a). These features justify the hypothesis of a well-established Acheulean tradition at c. 700 ka in Western Europe (Moncel et al. 2013, 2016, 2020a). Coupled with a geometric morphometric analysis using 3D models, this technological study of the LCTs tracks for the first time innovations $v$. common features and the degree of filiation between strata a and c for the heavy-duty component. Our method enables us to determine a large set of similar and different tool features related to shaping modes and final morphometry.

Data clearly distinguish the two different technological assemblages (stratum a and stratum c), regardless of raw material or blank types. In stratum a (Moncel et al. 2013, 2016, 2020a), a single local raw material is used, millstone slabs. Handaxe shaping retains large cortical surfaces and exploits stone geometry with one or two series of removals, mainly with hard hammers. This behaviour generates a few standardized assemblages. Nevertheless, technological control of the tips is also observed, using both hard and soft hammer percussion. We can also mention evidence of longer shaping chains on some tools (group of unknown blanks). On the other hand, stratum c is characterized by the use of diverse stones and the introduction of raw materials from long-distance areas. The use of local stones in stratum $\mathrm{c}$ indicates an increase in the size of the procurement zone, suggesting higher mobility for hominin groups at the end of MIS 12 and the beginning of MIS 11. The large majority of tools in this level present long reduction sequences, with at least two series of removals and final retouch, thinner tools, a widespread use of soft hammers on the whole tool, and less extensive cortical zones.

The tools made on indeterminate blanks in stratum a, with longer operative chains, are key to point to a possible filiation between the two levels. What was original and occasional in stratum a became generalized in stratum c. These new features also include the generalization of the use of soft hammer percussion and the widespread use of final retouch. Finally, an intensification of the technological features documented in the lower level is only observed on some pieces and a local raw material. This results in higher heterogeneity in tool cutting edge angles in stratum a, while in stratum c, more careful management of tool thickness and edges leads to increased homogeneity and more acute angles. In addition, the values of the angles between tips (30-45 ) and butts $\left(60-80^{\circ}\right)$ are differentiated.

From a morphometric point of view, there is a transition between the two levels from oval (globular) shapes and few standardized tools, with the maximum width of the tool at mid-length, to 'teardrop' shapes in a more homogeneous assemblage, with the maximum width of the tool at the base (Fig. 9). There is also a transition from short distal parts, with wider convex tips, to longer convergent edges with more pointed tips, opposed to wider bases. In addition, intense technological work on the tools of stratum c results in reduced tool thickness. As lovita stated (2017), Acheulean toolmakers had the technical abilities and skills to produce symmetric tools from 700 ka onwards. Nevertheless, there is an increase in this tool symmetry in stratum c. lovita and colleagues (2017) concluded that this symmetry was dependent on the degree of reduction and the raw material. The use of 3D models in the geometric morphometric analyses led us to go further and clarify this conclusion. Bilateral and bifacial symmetry increase on average by $25 \%$ and $35 \%$ respectively. Plan symmetry is mainly affected by the façonnage strategy, by more than one series of removals on the whole perimeter of the tool, reducing the thickness and modifying the original geometry of the blank whatever the raw material. Nevertheless, edge regularity depends on final edge retouch.

How should these differences between the two occupation phases be interpreted? Do they stem from local or on a broader scale innovations rooted in the past motivated by external or internal changes or do they represent a shift, as a result of a break in populations with new dispersals? At la Noira, our analysis on the total corpus of bifaces and bifacial tools highlights two main features. First, in stratum a, we do not observe any differences in shaping or in morphological results for different blank types, even if slabs predominate. Only some tools with longer sequences stand out from the rest of the corpus $(n=4,12.9 \%)$ due to more intense shaping, making it impossible to identify the type of blank. The tools present a combination of soft and hard hammer percussion and more intensive final retouch. Consequently, the hominins of stratum a were able to develop complex and versatile operative chains. 
Should we consider that this ability at $700 \mathrm{ka}$ is evidence of a technological filiation between populations from MIS 16 to MIS 11 ? If we look at the results of the geometric morphometric analysis, we do not observe real morphological breaks between the two corpuses despite the use of the same local stones and introduction of other types of stones and shapes in the stratum c. Handaxes from stratum a are not homogeneous and short shaping sequences are correlated with greater tool thickness. Morphometrically, the complexity of this biface production at $700 \mathrm{ka}$ is observed in the ability to manage tool plan shape for oval shapes, placing the centre of the mass at the midpart of tools. The stratum c corpus is characterized by a higher standardization of shapes, creating wider bases opposed to thinner and more pointed tips. The use of several series of removals reduces tool thickness as we can observe in some sites in Western Europe (Ashton et al. 2012; Moncel et al. 2021a). We observe total control of volume and edge morphology, which become more regular. A filiation over time between the populations at la Noira (and Western European populations) is thus possible, suggesting that the long interglacial MIS 11 in Western Europe was not really a threshold and enabled local and European populations with internal evolution to re-occupy abandoned areas when the climate became more favourable, facilitating demographic expansion and the implementation of more complex strategies. Understanding shifts in human behavioural evolution is a challenge because illustrating abilities to hominins to evolve over time and increase skills and cognition whatever environmental conditions and without necessary introduction by dispersals of new populations. The anatomical diversity of Homo heidelbergensis and other fossils such as Ceprano skull suggests an intra or inter diversity of hominins into Europe and raise question on the behavioural process in parallel to the earliest Neanderthal features (Manzi et al. 2010). La Noira site brings a new step forwards to better describe this process, possibly finding roots in the past. It also contributes to understand the own rhythms of human evolution both for the behaviours and the anatomical evolution.

\section{Conclusion}

La Noira (Center of France) suggest a punctual expansion of the Acheulean culture northwards the $45^{\text {th }}$ parallel, during MIS17. Data clearly distinguish the two different technological assemblages (stratum a and stratum c), regardless of raw material or blank types. In stratum a single local raw material is used. Handaxe shaping retains large cortical surfaces and exploits stone geometry with one or two series of removals, mainly with hard hammers. This behaviour generates a few standardized assemblages. Nevertheless, technological control of the tips is also observed, using both hard and soft hammer percussion. On the other hand, stratum $\mathrm{c}$ is characterized by the use of diverse stones and the introduction of raw materials from long-distance areas. The use of local stones in stratum c indicates an increase in the size of the procurement zone, suggesting higher mobility for hominin groups at the end of MIS 12 and the beginning of MIS 11. The large majority of tools in this level present longer reduction sequences, with at least two series of removals and final retouch, thinner tools, a widespread use of soft hammers on the whole tool, and less extensive cortical zones. The tools made on indeterminate blanks in stratum a, with longer operative chains, are key to point to a possible filiation between the two levels. The tools present a combination of soft and hard hammer percussion and more intensive final retouch. Consequently, the hominins of stratum a were able to develop complex and versatile operative chains.

We do not observe real morphological breaks between the two corpuses despite the use of the same local stones and introduction of other types of stones and shapes in the stratum c. There is a transition between the two levels from oval shapes and few standardized tools, with the maximum width of the tool at mid-length, to 'teardrop' shapes in a more homogeneous assemblage, with the maximum width of the tool at the base. There is also a transition from short distal parts, with wider convex tips, to longer convergent edges with more pointed tips, opposed to wider bases. Morphometrically, the complexity of this biface production at $700 \mathrm{ka}$ is observed in the ability to manage tool plan shape for oval shapes, placing the centre of the mass at the midpart of tools.

\section{Declarations}

\section{Acknowledgements}

This research was supported by the project "Understanding a threshold in Human evolution at 450-350 ka through the roots of Neanderthal behavior (Neandroots)" (ANR-19-CE27-0011). P.García-Medrano received a grant from the European Union's Horizon 2020 research and innovation programme as part of a Marie Sklodowska-Curie project, "Western European Acheulean project, WEAP" (Gran Agreement n.748316). The University of Bradford and Dr. Adrian Evans, through the "Fragmented Heritage AHRC Project", lent us the scanner for the work. We are particularly grateful to the Hebrew University of Jerusalem, Dr. Leore Grosman and Antoine Muller, who helped us with the Artifact3-D and AGMT3-D software management. This work was developed at the https://www.fondationiph.org, the Dpt. Britain, Europe and Prehistory at Franks House (British Museum), and the Institut Català de Paleoecologia Humana i Evolució Social (IPHES-CERCA, Spain). The latter has received financial support from the Spanish Ministry of Science and Innovation through the "María de Maeztu" program for Units of Excellence (CEX2019-000945-M)."

Page $9 / 27$ 


\section{Funding}

This research was supported by the project "Understanding a threshold in Human evolution at 450-350 ka through the roots of Neanderthal behavior (Neandroots)" (ANR-19-CE27-0011)

P.García-Medrano received a grant from the European Union's Horizon 2020 research and innovation programme as part of a Marie Sklodowska-Curie project, "Western European Acheulean project, WEAP” (Gran Agreement n.748316)

The Institut Català de Paleoecologia Humana i Evolució Social (IPHES-CERCA, Spain) has received financial support from the Spanish Ministry of Science and Innovation through the "María de Maeztu” program for Units of Excellence (CEX2019-000945-M)

\section{Conflict of interes:}

Not applicable

\section{Availability of data and material:}

3D Models from La Noira site (Central France) [Data set]. ZENODO. https://doi.org/10.5281/zenodo.4415985

\section{Code availability}

Not applicable

\section{Author's contributions}

The three authors contributed to this work. M.H.M. and J.D. directed the excavation work. P.G. and M.H.M. analysed the materials and wrote the paper. P.G.M took all pictures and 3D models. All authors reviewed the manuscript.

\section{Ethics approval}

Not applicable

\section{Consent to participate}

Not applicable

\section{Consent for publication}

Not appicable

\section{References}

1. Abbate E, Sagri M (2012) Early to Middle Pleistocene Homo dispersals from Africa to Eurasia: Geological, climatic and environmental constraints. Quaternary International 267: 3-19

2. Almogi-Labin A (2011) The paleoclimate of the Eastern Mediterranean during the transition from early to mid Pleistocene (900 to 700 ka) based on marine and non-marine records: An integrated overview. Journal of Human Evolution 60(4): 428-436

3. Ashton N, Lewis JE, Hosfield R (2011) Mapping the human record: Population change in Britain during the Early Palaeolithic. In: Ashton N, Lewis JE, Stringer C (eds) The Ancient Human Occupation of Britain. Developments in Quaternary Sciences, 14. Elsevier, pp $39-53$

4. Ashton N, Lewis SG (2012) The environmental contexts of early human occupation of northwest Europe: The British Lower Palaeolithic record. Quaternary International 271: 50-64 
5. Bar-Yosef O, Belmaker M (2011) Early and Middle Pleistocene Faunal and hominins dispersals through Southwestern Asia. Quaternary Science Reviews 30: 1318-1337

6. Blain HA, Fagoaga A, Ruiz-Sánchez FJ, García-Medrano P, Ollé A, Jiménez-Arenas, JM (2021) Coping with arid environments: a critical threshold for human expansion in Europe at the MIS 12/11 transition? The case of the Iberian Peninsula. Journal of Human Evolution 153: 102950 https://doi.org/10.1016/j.jhevol.2021

7. Bordes F (1961) Typologie du Paléolithique Ancien et Moyen. Delmas, Bordeaux

8. Boëda É, Geneste JM, Meignen L (1990) Identification de chaînes opératoires lithiques du Paléolithique ancien et moyen. Paléo 2: 4380

9. Candy I, Silva B, Lee J (2011) Climates of the Early Middle Pleistocene in Britain: Environments of the Earliest Humans. In: Ashton N. Lewis JE, Stringer C (eds) The Ancient Human Occupation of Britain. Developments in Quaternary Sciences, 14. Elsevier, pp 11-22

10. Carbonell E, Bermúdez de Castro JM, Arsuaga JL, Díez JC, Rosas A, Cuenca-Bescós G et al (1995) Lower Pleistocene hominids and artefacts from Atapuerca-TD6 (Spain). Science 269: 826-830

11. Carrión JS, Rose J, Stringer C (2011) Early Human Evolution in the Western Palaearctic: Ecological Scenarios. Quaternary Science Reviews 30: 1281-1295

12. Carrión JS, Walker MJ (2019) Background to Neanderthal presence in Western Mediterranean Europe. Quaternary Science Reviews 217: $1-340$

13. Clark PU, Archer D, Pollard D, Blum JD, Rial JA et al (2006) The middle Pleistocene transition: Characteristics, mechanisms, and implications for long-term changes in atmospheric pCO2. Quaternary Science Reviews 25(23-24): 3150-3184

14. Clarkson C (2013) Measuring core reduction using 3D flake scar density: a test case of changing core reduction at Klasies River mouth, South Africa. Journal of Archaeological Science 40(12): 4348-4357

15. Costa AGA (2010) Geometric Morphometric assessment of Plan shape in bone and stone Acheulean bifaces from the Middle Pleistocene site of Castel di Guido, Latium, Italy. In: Lycett SL, Chauhan PRE (eds) New Perspectives on Old Stones: Analytical Approaches to Paleolithic Technologies. Springer, pp 23-41

16. Cuenca-Bescos G, Melero-Rubio M, Rofes J, Martinez I, Arsuaga JL et al (2011) The Early-Middle Pleistocene environmental and climatic change and the human expansion in Western Europe: A case study with small vertebrates (Gran Dolina, Atapuerca, Spain). Journal of Human Evolution 60(4): 481-491

17. Dennell RW, Martinón-Torrès M, Bermúdez de Castro JM (2011) Hominin variability, climatic instability and population demography in Middle Pleistocene Europe. Quaternary Science Reviews 30: 1511-1524

18. de la Torre I, Mora R, Martínez-Moreno J (2008) The early Acheulean in Peninj (Lake Natron, Tanzania). Journal of Anthropological Archaeology 27: 244-264

19. Dépont J (1984) Une industrie acheuléenne dans son contexte géologique: la sablière des Fougères à Brinay (Cher). Cahiers d'Archéologie et d'Histoire du Berry 78 : 19-31

20. Despriée J, Voinchet P, Tissoux H, Bahain JJ, Falguères C et al (2011) Lower and Middle Pleistocene human settlements recorded in fluvial deposits of the middle Loire River Basin, Centre Region, France. Quaternary Science Reviews 30(11-12): 1474-1485

21. Despriée J, Courcimault G, Moncel MH, Voinchet P, Tissoux H, Puaud S, Gallet X, Bahain JJ, Moreno D, Falgueres C (2016) The Acheulean site of la Noira (Centre region, France): characterization of materials and alterations, choice of lacustrine millstone and evidence of anthropogenic behavior. Quaternary International. SI 'European Acheulean' 411: 144-159

22. Despriée J, Voinchet $P$, Courcimault G, Bahain JJ, Puaud S et al (2017a) Le site pléistocène moyen de la Noira à Brinay (Cher, région Centre, France): contexte morphosédimentaire, géochronologie et données archéologiques. Quaternaire 28(1): 31-48

23. Despriée J, Courcimault G, Voinchet P, Puaud S, Bahain JJ et al (2017b) Etude géoarchéologique du site acheuléen ancien de la Noira, (Brinay, Cher, région Centre, France). Quaternaire 28(1): 49-72

24. Despriée J, Courcimault G, Voinchet P, Jouanneau JC, Puaud S et al (2017c) Le site du Pléistocène inférieur de Lunery-Rosières, la Terre-des-Sablons (France, région Centre, Cher): unités sédimentaires, datations ESR, études géoarchéologiques, Préhistoire. Quaternaire 28(1): 5-30

25. Elderfield H, Ferretti P, Greaves M, Crowhurst S, McCave IN et al (2012) Evolution of Ocean Temperature and Ice Volume through the Mid-Pleistocene Transition. Nature 337: 704-709

26. García-Medrano P (2020) 3D Models from La Noira site (Central France) [Data set]. ZENODO. https://doi.org/10.5281/zenodo.4415985 
27. García-Medrano P, Ollé A, Roberts MB, Ashton N (2019) The mental template in handaxe manufacture: New insights into Acheulean lithic technological behaviour at Boxgrove, Sussex, UK. Journal of Archaeological Method and Theory 26: 396-422

28. García-Medrano P, Ashton N, Moncel M, Ollé A (2020) The WEAP Method: a New Age in the Analysis of the Acheulean Handaxes. Journal of Paleolithic Archaelogy 3: 756-793

29. Gowlett JAJ (2006) The early settlement of northern Europe: Fire history in the context of climate change and the social bray. C.R. Palevol 5(1-2): 299-311.

30. Guthrie RD (1984) Mosaics, allelochemics and nutrients: An ecological theory of Late Pleistocene megafaunal extinctions. In Martin PS, Klein RG (eds) Quaternary extinctions: A prehistoric revolution. University of Arizona Press, pp 259-298

31. Hammer Ø, Harper DAT (2006) Paleontological Data Analysis. Malden. Blackwell Publishing

32. Hardy BL, Moncel MH, Despriée J, Courcimault G, Voinchet P (2018) Clues to Homo heidelbergensis Behavior at the 700ka Acheulean site of La Noira (France). Quaternary Sciences Review 199: 60-82

33. Herzlinger G, Grosman L (2018) AGMT3-D: A software for 3-D landmarks-based geometric morphometric shape analysis of archaeological artifacts. PLoSOne 13(11): e0207890

34. Herzlinger, G. \& Goren-Inbar N. Beyond a Cutting Edge: a Morpho-technological Analysis of Acheulian Handaxes and Cleavers from Gesher Benot Ya'aqov, Israel. J Paleo Arch 3, 33-58 (2020).

35. lovita R, Tuvi-Arad I, Moncel MH, Despriée J, Voinchet P, Bahain JJ (2017) High handaxe symmetry at the beginning of the European Acheulian: the data from la Noira (France) in context. PLosOne 12(5): e0177063

36. Jouzel J, Masson-Delmotte V, Cattani O, Dreyfus G, Falourd S, et al. (2007) Orbital and Millennial Antarctic Climate Variability over the Past 800,000 Years. Science Reports 317: 793-796

37. Leakey MD (1971) Olduvai Gorge: Excavations in Bed I and Bed II, 1960-1963. Cambridge University Press.

38. MacDonald K, Martinez-Torres M, Dennell RW, Bermúdez de Castro JM (2012) Discontinuity in the record for hominin occupation in south-western Europe: Implications for occupation of the middle latitudes of Europe. Quaternary International 271: 84-9

39. Manzi G (2004) Human Evolution at the Matuyama-Brunhes boundary. Evolutionary Anthropology 13: 11-24

40. Manzi G, Magri D, Milli S, Palombo MR, Margari V, Celiberti V, et al. (2010). The new chronology of the Ceprano calvarium (Italy). Journal of human evolution 59(5): 580-585.

41. McPherron S (2006) What typology can tell us about Acheulian handaxe production. In Goren Inbar N, Sharon G (eds) Axe Age: Acheulian Tool-making from Quarry to Discard. Equinox Publishing Ltd, pp. 267- 287

42. Messager E, Lebreton V, Marquer L, Russo-Ermolli E, Orain R, et al. (2011) Palaeoenvironments of early hominins in temperate and Mediterranean Eurasia: New palaeobotanical data from Palaeolithic key-sites and synchronous natural sequences. Quaternary Science Reviews 30: 1439-1447

43. Moncel MH, Despriée J, Voinchet P, Tissoux H, Moreno D, et al. (2013) Early evidence of Acheulean settlement in north-western Europe e la Noira site, a 700000 year-old occupation in the Center of France. PlosOne 8(11): e75529

44. Moncel MH, Ashton N, Lamotte A, Tuffreau A, Cliquet D, et al. (2015) The north-west Europe early Acheulian. Journal of Anthropological Archaeology 40: 302-331

45. Moncel MH, Arzarello M, Peretto C (2016) The Holstainian Eldorado. Quaternary International 409: 1-8

46. Moncel MH, Arzarello M, Boëda E, Bonilauri S, Chevrier B, et al. (2018a) Assemblages with bifacial tools in Eurasia (first part). What is going on in the West? Data on Western and Southern Europe and the Levant. C. R. Palevol 17(1-2): 45-60

47. Moncel MH, Arzarello M, Boëda E, Bonilauri S, Chevrier B, et al. (2018b) Assemblages with bifacial tools in Eurasia (second part). What is going on in the East? Data from India, Eastern Asia and Southeast Asia. C. R. Palevol 17(1-2): 61-76

48. Moncel MH, Landais A, Lebreton V, Combourieu-Nebout N, Nomade S, et al. (2018c) Linking environmental changes with human occupations between 900 and 400 ka in Western Europe. Quaternary International 480: 78-94

49. Moncel M, Despriée J, Courcimaut G, Boinchet P, Bahain JJ (2020a) La Noira Site (Centre, France) and the Technological Behaviours and Skills of the Earliest Acheulean in Western Europe Between 700 and 600 ka. J Paleo Arch 3: 255-301

50. Moncel MH, Santagata C, Pereira A, Nomade S, Voinchet P, Bahain JJ, et al. (2020b) The origin of early Acheulean expansion in Europe 700 ka ago: new findings at Notarchirico (Italy). Nature. Scientific Report 10(1): 1-16

51. Moncel MH, Ashton N, Arzarello M, Fontana F, Lamotte A, Scott B, et al. (2021a) An Early Levallois core technology between MIS 12 and 9 in Western Europe? Journal of Human Evolution 139: 102735

52. Moncel MH, García-Medrano P, Despriée J, Arnaud J, Voinchet P, Bahain JJ (2021b) Tracking behavioral persistence and innovations during the Middle Pleistocene in Western Europe. Shift in occupations between 700 ka and 450 ka at la Noira site (Centre, France).

Page $12 / 27$ 
Journal of Human Evolution 156: 103009

53. Mosquera M, Ollé A, Rodriguez XP (2013) From Atapuerca to Europe: Tracing the earliest peopling of Europe. Quaternary International 295: $130-137$

54. Muttoni G, Scardia G, Kent DV (2010) Human migration into Europe during the late Early Pleistocene climate transition. Palaeogeography, Palaeoclimatology, Palaeoecology 296: 79-93

55. Muttoni G, Scardia G, Kent DV (2018) Early hominins in Europe: The Galerian migration hypothesis. Quaternary Science Reviews 180: $1-29$

56. Newcomer MH (1971) Some quantitative experiments in handaxe manufacture. World Archaeology 3(1): 85-104

57. Nicoud E (2013a) What does the Acheulean consist of? The example of Western Europe (MIS 16-9). Mitteilungen der Gesellschaft für Urgeschichte 22: 41-60

58. Nicoud E (2013b) Complexité des stratigraphies regionals et nouveau modèle d'apparition et de diffusion du phénomène Acheuléen en Europe de l'Òuest. Quaternaire 24(4): 407-417

59. Ollé A, Mosquera M, Rodríguez XP, de Lombera-Hermida A, García-Antón MD, García-Medrano P, et al. (2013) The Early and Middle Pleistocene technological record from Sierra de Atapuerca (Burgos, Spain). Quaternary International 295: 138-167

60. Orain R, Lebreton V, Russo Ermolli E, Sémah AM, Nomade S, et al. (2013) Hominin responses to environmental changes during the Middle Pleistocene in central and southern Italy. Climate of the Past 9: 687-697

61. Paillard D (2015) Quaternary glaciations: From observations to theories. Quaternary Science Reviews 107: 11-24

62. Pereira A, Nomade $S$, Voinchet $P$, Bahain JJ, Falguères $C$, et al (2015) The earliest securely dated hominin fossil in Italy and evidence of Acheulian occupation during glacial MIS 16 at Notarchirico (Venosa, Basilicata, Italy). Journal of Quaternary Science 30(7): 639-650

63. Pereira A (2017) Apport de la datation 40AR/39AR à la compréhension de l'évolution culturelle des prénéandertaliens en Italie centrale et méridionale entre 750 et 250 ka. Thèse de doctorat. Museum National d'histoire naturelle de Paris, Ecole Française de Rome et Université de Ferrare

64. Peretto C, Arzarello M, Bahain JJ, Boulbes N, Dolo JM, et al. (2016) The Middle Pleistocene site of Guado San Nicola (Monteroduni, Central Italy) on the Lower/ Middle Palaeolithic transition. Quaternary International 411B: 301-315

65. Roche H (2005) From simple flaking to shaping: Stone-knapping evolution among early hominids. In Roux V, Brill B (eds) Stone knapping. The necessary conditions for a uniquely hominin behaviour, pp. 35-53

66. Roche H, Brugal JPh, Delagnes A, Feibel C, Harmand S, et al. (2003) Les sites archéologiques plio-pléistocènes de la formation de Nachukui, Ouest-Turkana Kenya : bilan synthétique 1997-2001. C.R.Palevol 2: 663-673

67. Rodríguez J, Burjachs F, Cuenca-Bescós G, García N, Made J, et al. (2011) One million years of cultural evolution in a stable environment at Atapuerca (Burgos, Spain). Quaternary Science Reviews 30: 1396-1412

68. Rodríguez-Hidalgo A, Saladié P, Ollé A, Arsuaga JL, Bermúdez de Castro JM, et al. (2017) Human predatory behavior and the social implications of communal hunting based on evidence from the TD10.2 bison bone bed at Gran Dolina (Atapuerca, Spain). Journal of Human Evolution 105: 89-122

69. Roe DA (1994) A metrical analysis of selected sets of handaxes and cleavers from Olduvai Gorge. In Leakey MD, Roe MD (eds) Olduvai Gorge 5 Cambridge University Press, pp. 146-234

70. Renfrew C (1978) The anatomy of innovation. In: Green D, Haselgrove C, Spriggs M (eds) Social Organisation and Settlement. BAR Series 47, pp. 89-117

71. Roe D (1968) A. British Lower and Middle Palaeolithic Handaxe Groups. Proceedings of the Prehistoric Society 34: 1-82

72. Stout D (2011) Stone toolmaking and the evolution of human culture and cognition. Philos. Trans. R. Soc. B Biol. Sci. 366: 1050-1059

73. Schreve D, Moncel MH, Bridgland D (2015) The early Acheulean occupation of western Europe: chronology, environment and subsistence behaviour. In: Schreve D, Moncel, MH, Bridgland D (eds) Chronology, paleoenvironments and subsistence in the Acheulean of western Europe. Journal of Quaternary Science SI 30(7): 585-593

74. Shen G, Michel V, Despriée J, Han F, Granger DE (2012) Datation d'enfouissement par 26Al/10Be et son application préliminaire à des sites du Paléolithique inférieur de Chine et en France. L'Anthropologie 116(1): 1-11

75. Shipton C. Clarkson C, Pal JN, Jones SC, Roberts RG, et al. (2013) Generativity, hierarchical action and recursion in the technology of the Acheulean to middle Palaeolithic transition: A perspective from Patpara, the Son Valley, India. Journal of Human Evolution 65(2): 93-108

76. Shipton C, Clarkson C (2015a) Flake scar density and handaxe reduction intensity. Journal of Archaeological Science: Reports 2: 169175

Page 13/27 
77. Shipton C, Clarkson C (2015b) Handaxe reduction and its influence on shape: An experimental test and archaeological case study. Journal of Archaeological Science: Reports 3: 408-419

78. Texier PJ (2001) Du seuil de l'hominisation aux premières cultures : potentialité et apports de la taille expérimentale. Praehistoria 2: 51-61

79. Texier PJ (2018) Technological Assets for the Emergence of the Acheulean? Reflexions on the Kokiselei 4 Lithic Assemblage and its place in the Archaeological Context of West Turkana, Kenya. In Gallotti R, Mussi M (eds) The Emergence of the Acheulean in East Africa and Beyond. Contributions in Honor of Jean Chavaillon. Springer, pp. 33-52

80. Wenban-Smith FF (1989) The use of canonical variates for determination of biface manufacturing technology at Boxgrove Lower Palaeolithic site and the behavioural implications of this technology. Journal of Archaeological Science 16: 17-26

81. Wymer JJ (1968) Lower Palaeolithic archaeology in Britain as represented by the Thames Valley. London: John Baker.

82. Wynn T (2002) Archaeology and cognitive evolution. Behavioural and Brain Sciences 25(3): 389-402.

\section{Tables}

\section{Table 1}

All categories documented at strata a and c from la Noira (Moncel et al. 2021b)

\begin{tabular}{lllll} 
& \multicolumn{2}{c}{ Stratum a } & \multicolumn{2}{c}{ Stratum c } \\
\cline { 2 - 5 } & $(\mathrm{N})$ & $\%$ & $(\mathrm{~N})$ & $\%$ \\
\hline Broken slabs and slabs with impact points & 246 & 26.8 & - & - \\
\hline Slabs with few removals & 84 & 9.1 & - & - \\
\hline Cores & 47 & 5.1 & 34 & 6.3 \\
\hline Cores or heavy-duty tools & 8 & 0.8 & 11 & 2 \\
\hline Flakes (unretouched) & 341 & 37.2 & 332 & 61.8 \\
\hline Flake-tools & 104 & 11.3 & 62 & 11.5 \\
\hline Preforms of heavy-duty tools & 4 & 0.4 & - & - \\
\hline Bifaces and bifacial tools & 19 & 2.1 & 74 & 13.8 \\
\hline Cleavers on flake & 2 & 0.2 & 2 & 0.3 \\
\hline Bifacial cleavers or cleavers-like & 8 & 0.8 & - & - \\
\hline Heavy-duty tools & 39 & 4.2 & 9 & 1.6 \\
\hline Products of the shaping & 16 & 1.6 & 13 & 2.4 \\
\hline Total & 918 & - & 537 & - \\
\hline
\end{tabular}

Table 2

Technological features and linear measurements considered to analyze LCT according to the WEAP Method. 


\begin{tabular}{|c|c|c|}
\hline \multicolumn{3}{|c|}{ WEAP Method: Technological features } \\
\hline \multicolumn{3}{|c|}{ LCT as one sole unit } \\
\hline Variable & Categories & Description \\
\hline Raw material & Type & $\begin{array}{l}\text { Flint, chert, quartzite, quartz, limestone and other metamorphic } \\
\text { rocks }\end{array}$ \\
\hline \multirow[t]{4}{*}{ Blank type } & Blocks & Broken from bedrocks \\
\hline & Nodules & Eroded from bedrocks \\
\hline & Cobbles & From river gravels \\
\hline & Flakes & Detached from cobbles/nodules \\
\hline \multirow[t]{3}{*}{ Number of faces } & Unifacial & Only one shaped face \\
\hline & Bifacial & Two shaped faces \\
\hline & Trifacial & Three shaped faced \\
\hline \multirow[t]{4}{*}{ Cortex localization } & Tip & Cortex only on tip \\
\hline & Mid & Cortex on mid part \\
\hline & Butt & Cortex on butt part \\
\hline & All & Cortex along the whole piece \\
\hline \multirow[t]{3}{*}{ Edge delineation } & Straight & In profile view \\
\hline & Sinuous & \\
\hline & Curved & \\
\hline \multirow[t]{2}{*}{ Symmetry } & SIM & Symmetric profile \\
\hline & NSIM & Non-symmetric profile \\
\hline Number of scars & $(\mathrm{N})$ & Counted per face \\
\hline \multicolumn{3}{|c|}{ LCT for each morpho-functional part (tip, mid and butt) } \\
\hline Variable & Categories & Description \\
\hline \multirow[t]{3}{*}{ Hammer used } & Hard & \\
\hline & Soft & \\
\hline & Combined & \\
\hline Presence of Cortex & $\%$ & \\
\hline \multirow{5}{*}{$\begin{array}{l}\text { Removal Series } \\
\text { ^Add as many as needed }\end{array}$} & 1 & One removal series \\
\hline & 2 & Two removal series \\
\hline & $3 \ldots$ & Three removal series (or more) \\
\hline & $\begin{array}{l}\text { Final } \\
\text { Retouch }\end{array}$ & Could be a removal series by itself \\
\hline & Combined & The combination of these series \\
\hline \multirow[t]{2}{*}{ Depth scars on edge } & Deep & Generating denticulate edges \\
\hline & Marginal & Creating continuous edges \\
\hline \multirow[t]{2}{*}{$\begin{array}{l}\text { Invasiveness (scars on tool's surface) *analyse } \\
\text { each series of removals }\end{array}$} & $\begin{array}{l}\text { Non- } \\
\text { invasive }\end{array}$ & Removals close to the edge \\
\hline & Invasive & Removals affecting $\geq 50 \%$ of piece \\
\hline Final Retouch & $\begin{array}{l}\text { Non- } \\
\text { invasive }\end{array}$ & Removals close to the edge \\
\hline
\end{tabular}

Page 15/27 


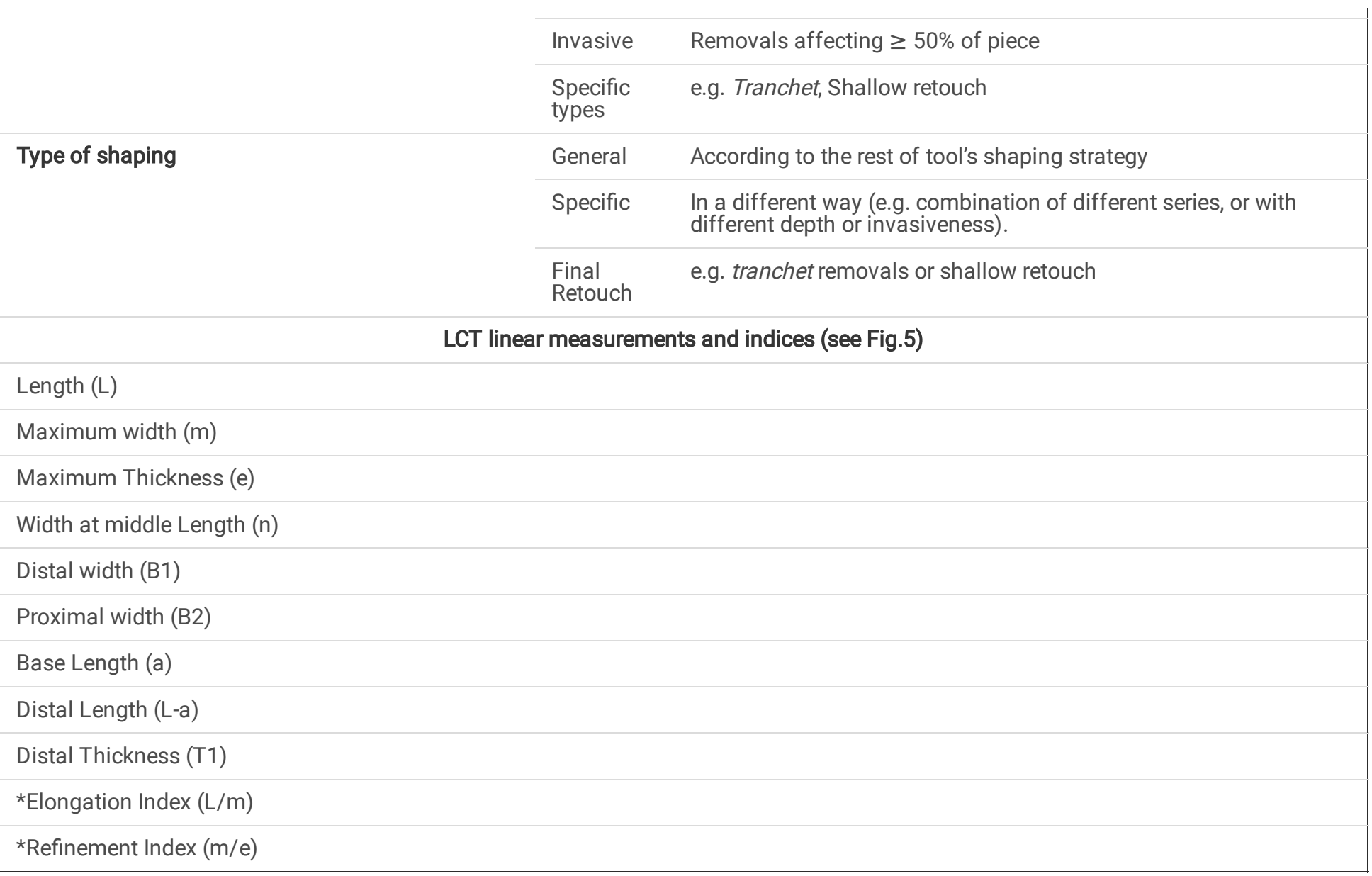

Table 3

Number (N) of LCTs and frequencies (\%) in stratum a and stratum c, raw material type and type of blank.

\section{Stratum a}

\begin{tabular}{|c|c|c|c|c|c|c|c|c|c|c|c|c|c|c|c|c|}
\hline & \multicolumn{2}{|c|}{ Slab } & \multicolumn{2}{|c|}{ Flake } & \multicolumn{2}{|c|}{ Unknown } & \multicolumn{2}{|c|}{ TOTAL } & \multicolumn{2}{|c|}{ Slab } & \multicolumn{2}{|c|}{ Flake } & \multicolumn{2}{|c|}{ Unknown } & \multicolumn{2}{|c|}{ TOTAL } \\
\hline & $(\mathrm{N})$ & $\%$ & $(\mathrm{~N})$ & $\%$ & (N) & $\%$ & $(\mathrm{~N})$ & $\%$ & $(\mathrm{~N})$ & $\%$ & $(\mathrm{~N})$ & $\%$ & (N) & $\%$ & $(\mathrm{~N})$ & $\%$ \\
\hline Millstone & 20 & 64.52 & 7 & 22.58 & 4 & 12.90 & 31 & 100.00 & 11 & 47.83 & 5 & 21.74 & 7 & 30.43 & 23 & 48.94 \\
\hline $\begin{array}{l}\text { Flint \& } \\
\text { silicific. }\end{array}$ & - & - & - & - & - & - & - & - & 7 & 29.17 & 8 & 33.33 & 9 & 37.50 & 24 & 51.06 \\
\hline TOTAL & 20 & 64.52 & 7 & 22.58 & 4 & 12.90 & 31 & & 18 & 38.30 & 13 & 27.66 & 16 & 34.04 & 47 & \\
\hline
\end{tabular}

Table 4

Intra-assemblage shape variability (measured as the mean multidimensional Euclidean distance of all artefacts from its centroid) and distribution of relative shape variability across dimensions (calculated as the proportion of variability in each homologous semi-landmark coordinate for each specific dimension). 


\begin{tabular}{llllll} 
& & \multicolumn{5}{c}{ variability (\%) caused by } \\
& $\mathbf{( N )}$ & Shape variability & $\mathbf{x}$ (width) & $\mathbf{y}$ (length) & $\mathbf{z}$ (thickness) \\
\hline Stratum a & $\mathbf{3 1}$ & 348.42 & 47.73 & 5.97 & 46.30 \\
\hline Stratum C & $\mathbf{4 7}$ & 321.2 & 38.85 & 4.84 & 56.31 \\
\hline Millstone_a & $\mathbf{3 1}$ & 348.42 & 47.73 & 5.97 & 46.30 \\
\hline Millstone_c & $\mathbf{2 3}$ & 308.90 & 37.60 & 3.52 & 58.88 \\
\hline Flint_c & $\mathbf{2 4}$ & 325.75 & 40.36 & 5.89 & 53.74
\end{tabular}

Table 5

MANOVA analysis on first 10 PC scores (74\% of variance) from Figure 7 , between stratum a and stratum c from la Noira and raw materials.

\begin{tabular}{llll} 
& Stratum a Millstone & Stratum c Flint & Stratum c Millstone \\
\hline Stratum a Millstone & & 0.0001069 & 0.0002223 \\
\hline Stratum c Flint & 0.0001069 & & 0.6544600 \\
\hline Stratum c Millstone & 0.0002223 & 0.6544600 &
\end{tabular}

Table 6

Descriptive statistics (mean and standard deviation, SD) and coefficients of variation (CV) for the six edge angles considered, for strata a and $\mathrm{c}$ of la Noira.

\begin{tabular}{llllllll} 
& & Distal & $\mathbf{1 / 5}$ & $\mathbf{2 / 5}$ & $\mathbf{3 / 5}$ & $\mathbf{4 / 5}$ & Proximal \\
\hline \multirow{2}{*}{ Str. $\boldsymbol{a}$} & Mean & 46.87 & 59.29 & 66.7 & 71 & 75.38 & 74.4 \\
\cline { 2 - 7 } & SD & 13.69 & 11.22 & 9.82 & 11.18 & 11.2 & 16.11 \\
\cline { 2 - 7 } & CV & 0.29 & 0.18 & 0.14 & 0.15 & 0.14 & 0.21 \\
\hline Str. c & Mean & 34.22 & 50.00 & 60.26 & 64.94 & 68.28 & 73.74 \\
\cline { 2 - 7 } & SD & 7.38 & 10.86 & 12.74 & 11.05 & 12.01 & 16.09 \\
\cline { 2 - 7 } & CV & 0.21 & 0.21 & 0.21 & 0.17 & 0.17 & 0.21
\end{tabular}

Table 7

ANOVA statistical test between SDI values and volume according to raw material type and the type of blank between strata a and c of la Noira. 


\begin{tabular}{|c|c|c|c|c|c|}
\hline & & $\mathbf{N}$ & $F$ & p & $r^{2}$ \\
\hline \multirow[t]{4}{*}{ Stratum a } & Millstone & 31 & 11.07 & $\otimes 0.01$ & 0.27 \\
\hline & Slab & 20 & 7.03 & 0.01 & 0.28 \\
\hline & Flake & 7 & 1.69 & 0.25 & 0.25 \\
\hline & Unknown & 4 & 5.34 & $\varangle 0.1$ & 0.72 \\
\hline \multirow[t]{5}{*}{ Stratum c } & Millstone & 20 & 6.73 & 0.01 & 0.27 \\
\hline & Flint & 21 & 13.85 & $\otimes 0.01$ & 0.42 \\
\hline & Slab & 15 & 3.42 & $\otimes 0.01$ & 0.20 \\
\hline & Flake & 11 & 6.79 & $\otimes 0.01$ & 0.42 \\
\hline & Unknown & 15 & 15.44 & $\otimes 0.01$ & 0.54 \\
\hline
\end{tabular}

\section{Table 8}

Summary statistics for deviations from perfect bilateral and bifacial symmetry and edge irregularity.

\begin{tabular}{|c|c|c|c|c|}
\hline & & \multirow{2}{*}{$\begin{array}{l}\text { Stratum a } \\
\text { Millstone }\end{array}$} & \multicolumn{2}{|c|}{ Stratum c } \\
\hline & & & Flint & Millstone \\
\hline \multirow[t]{5}{*}{ Deviation from perfect bilateral symmetry } & Max & 19.82 & 13.61 & 9.41 \\
\hline & Median & 6.08 & 5.50 & 5.07 \\
\hline & Min & 2.62 & 2.36 & 2.93 \\
\hline & Mean & 7.06 & 5.66 & 5.17 \\
\hline & Std Dev & 3.49 & 2.72 & 1.52 \\
\hline \multirow[t]{5}{*}{ Deviation from perfect bifacial symmetry } & Max & 15.27 & 11.81 & 6.58 \\
\hline & Median & 6.05 & 5.13 & 3.38 \\
\hline & Min & 2.81 & 2.11 & 2.48 \\
\hline & Mean & 6.18 & 5.12 & 3.99 \\
\hline & Std Dev & 2.79 & 2.21 & 1.28 \\
\hline \multirow[t]{5}{*}{ Left edge irregularity } & Max & 319.46 & 188.68 & 162.02 \\
\hline & Median & 109.44 & 83.80 & 76.12 \\
\hline & Min & 41.31 & 48.43 & 39.88 \\
\hline & Mean & 124.76 & 86.16 & 85.06 \\
\hline & Std Dev & 69.16 & 34.14 & 35.01 \\
\hline \multirow[t]{5}{*}{ Right edge irregularity } & Max & 293.25 & 200.22 & 229.58 \\
\hline & Median & 97.96 & 89.21 & 107.79 \\
\hline & Min & 51.78 & 26.54 & 45.37 \\
\hline & Mean & 122.99 & 90.81 & 112.68 \\
\hline & Std Dev & 64.37 & 46.50 & 49.11 \\
\hline
\end{tabular}




\section{Figures}
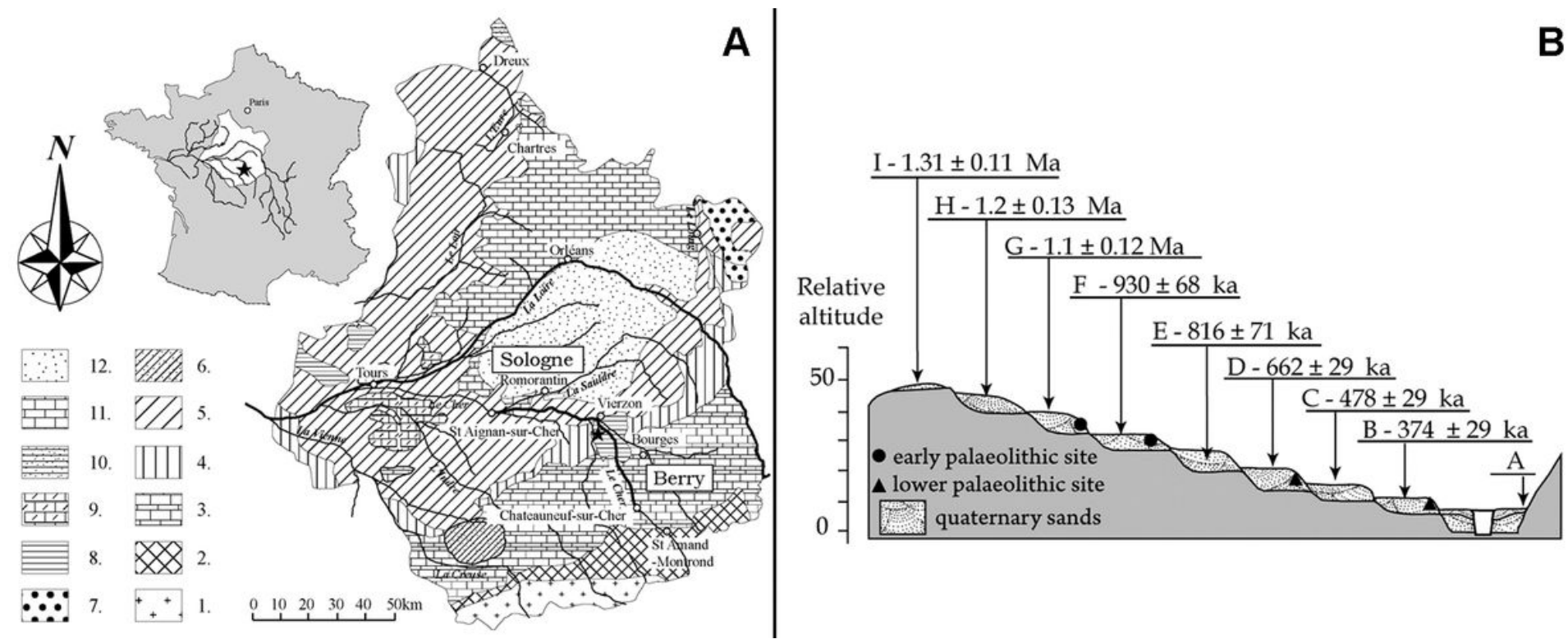

Figure 1

A) Simplified geological map of the Berry Region. B) Schematic stratigraphic section of the upper part of the western section of La Noira quarry: Sandy beds and erosional surface of stratum b, superposition of strata c and d with location of Acheulean artefacts and ESR samples (Moncel et al. 2020a) 


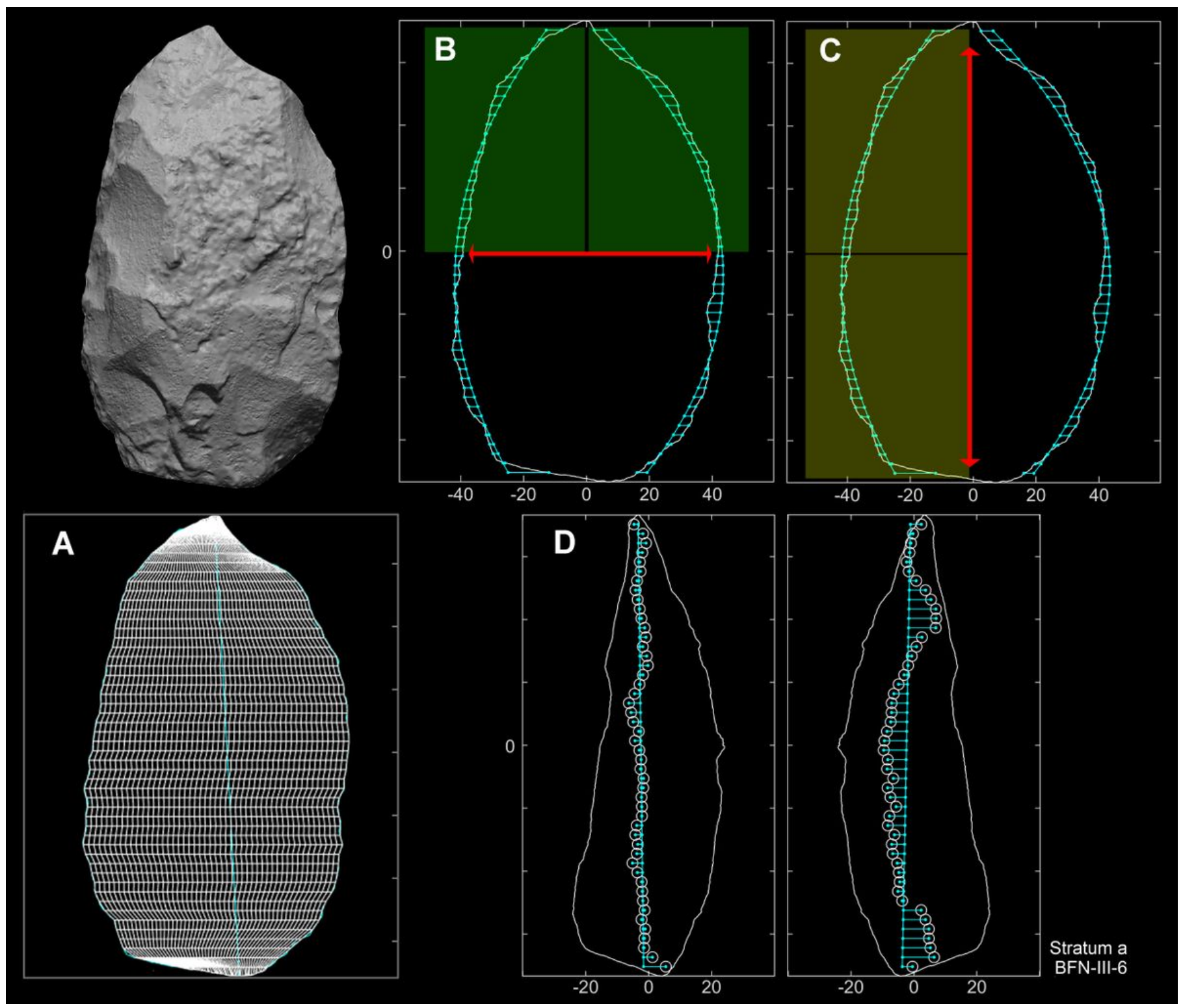

\section{Figure 2}

A) 5,000 points defining outlines and tool surfaces; B) Edge curvature: visualization of deviation from perfect bilateral symmetry (in green), and from perfect bifacial symmetry (in yellow). C) Edge irregularity. 


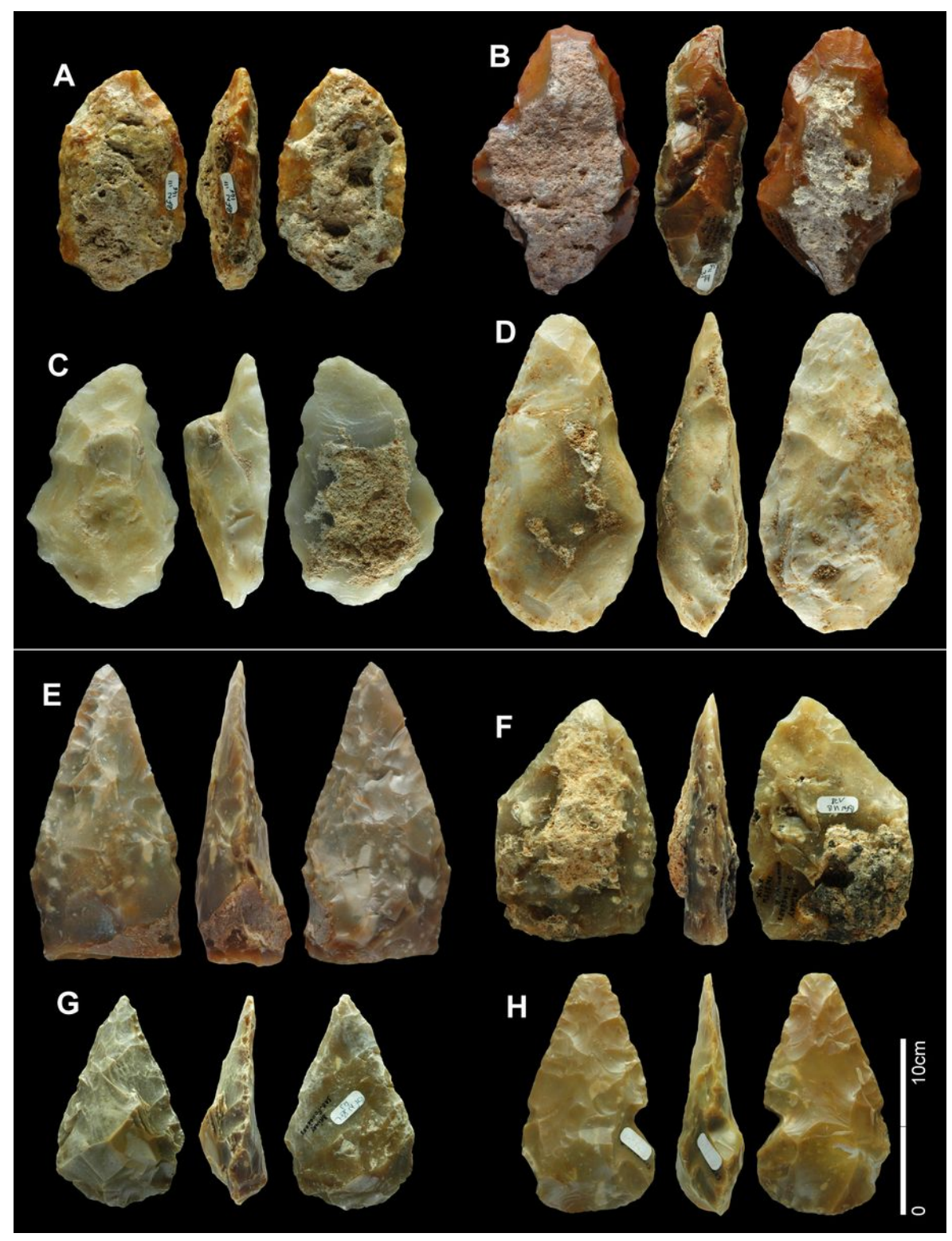

\section{Figure 3}

Handaxes from la Noira, stratum a (A, BFN III 146; B, BFN III 39; C, BFLN E1 d2 2; D, BFLN 0C5 d1 1) and stratum c (E, BFN SN; F, BFN VI 62; G, BFN VIb 178; H, BFN VIc 45). 


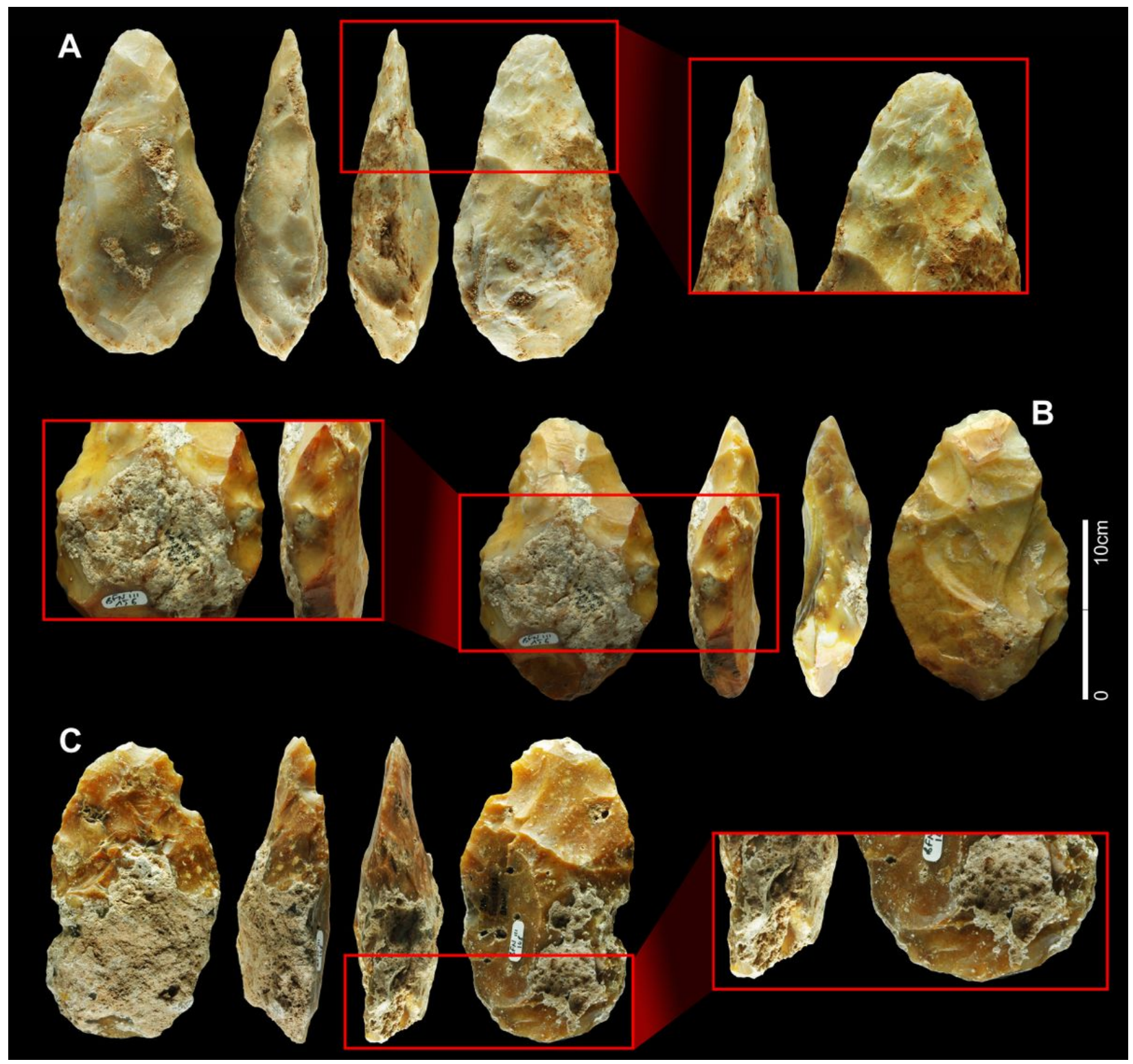

Figure 4

Technological characteristics of handaxes from stratum a of la Noira (A, BFLN 0C5 d1 1; B, BFN III 156; C, BFN III 148). 


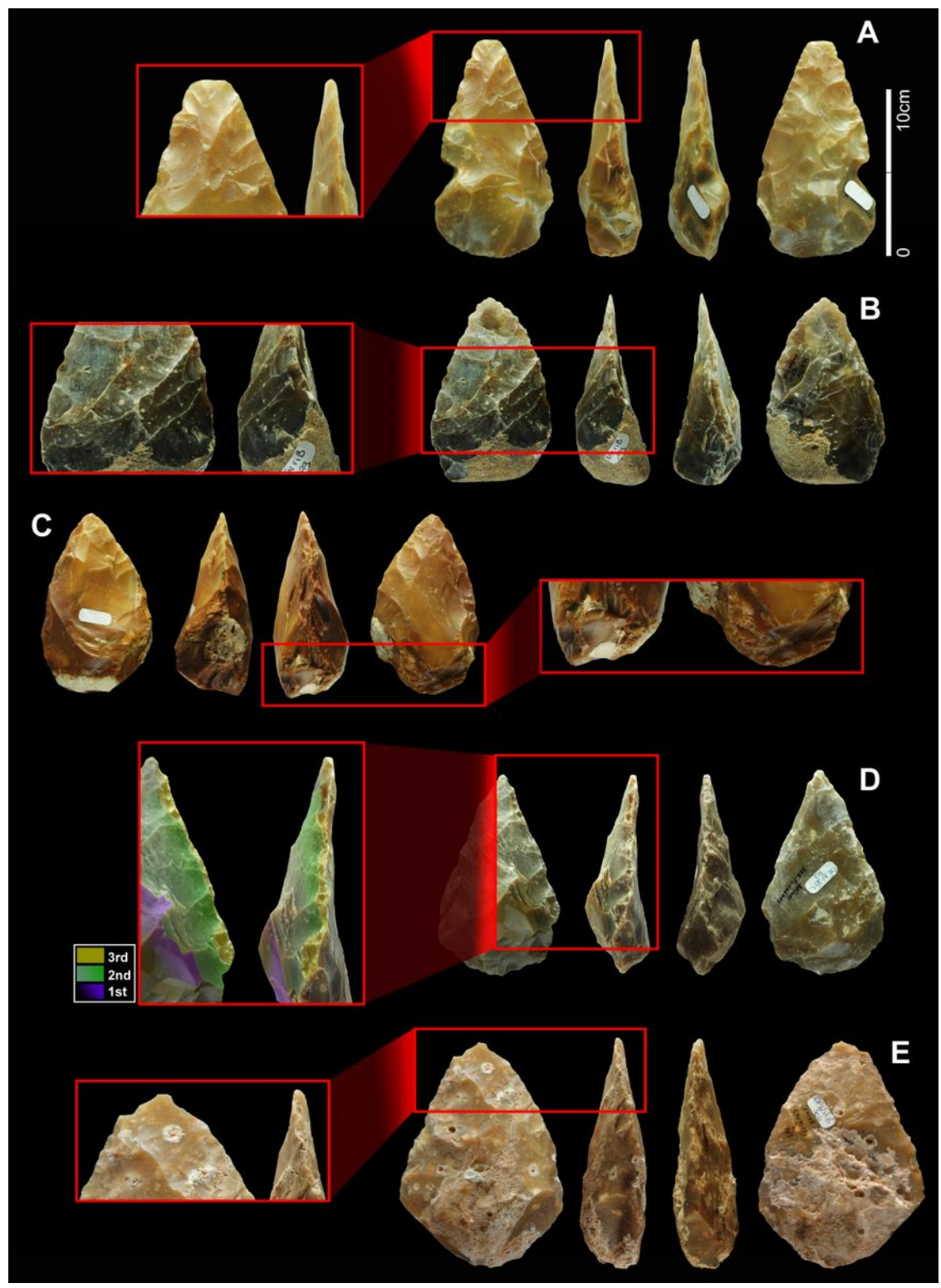

\section{Figure 5}

Technological characteristics of handaxes from stratum c of la Noira (A, BFN VI 62; B, BFN Vb 179; C, BFN VI 22; D, BFN Vic 45; E, BFN VIb 304). 

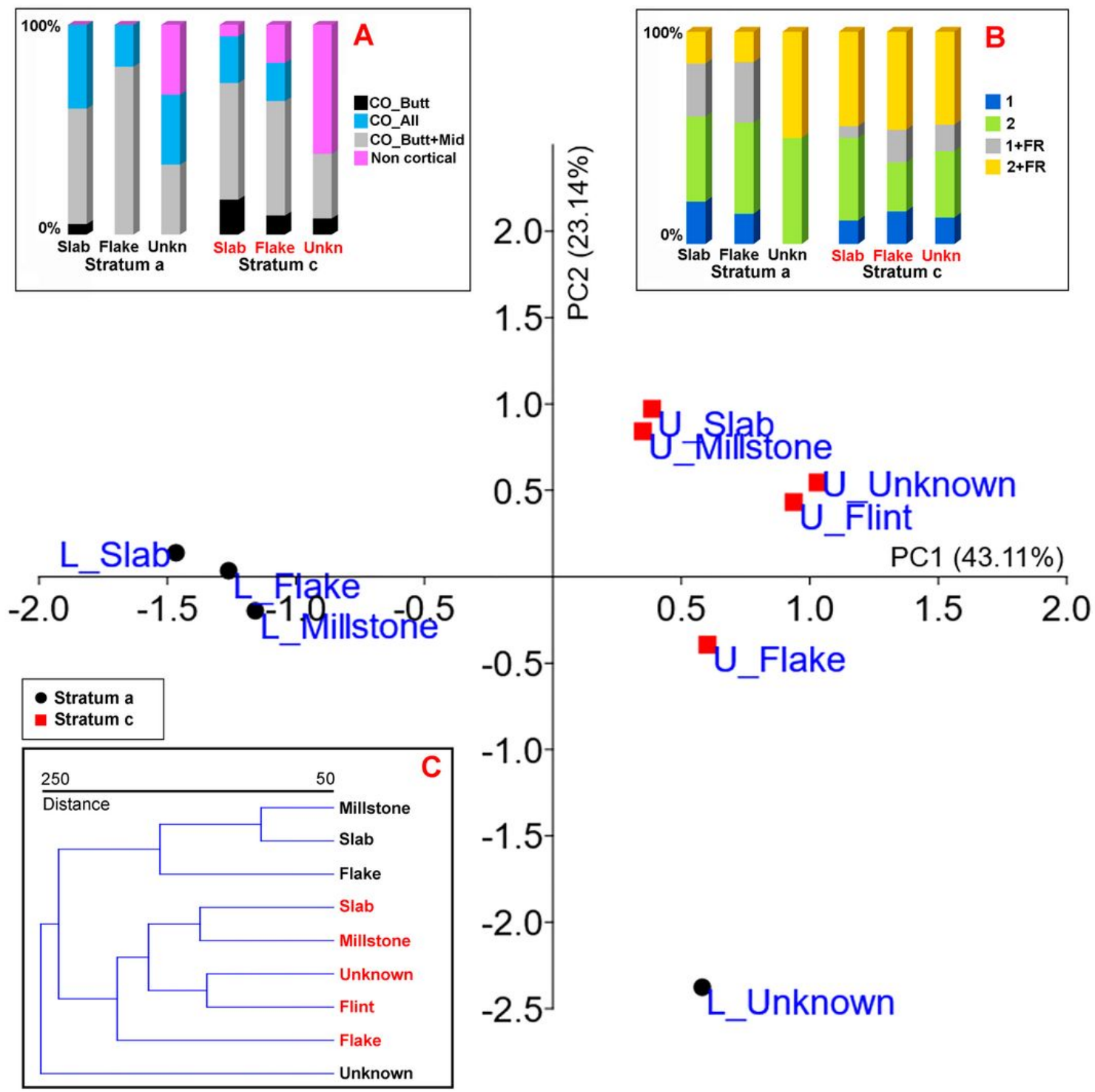

Figure 6

Principal Component Analysis of the technological features considered for the analysis of handaxes and cleaver-like tools: Handaxe as a single unit (A); Handaxes as three different parts (Tip, B; Midpart, C; Butt, D). The distribution represents the sample divided into stratum a $(\mathrm{L})$ and stratum $\mathrm{c}(\mathrm{U})$ levels, the type of blank (Slab, Flake and Unknown, blank dot) and type of raw material (Millstone and Flint red squares). Graphic A, distribution of Corticality between strata a and $\mathrm{c}$ and the type of blank identified; Graphic B, Removal series combinations in strata a and $\mathrm{c}$ and blank type; Graphic $\mathrm{C}$, Cluster analysis and distances between the groups represented in PCA. 


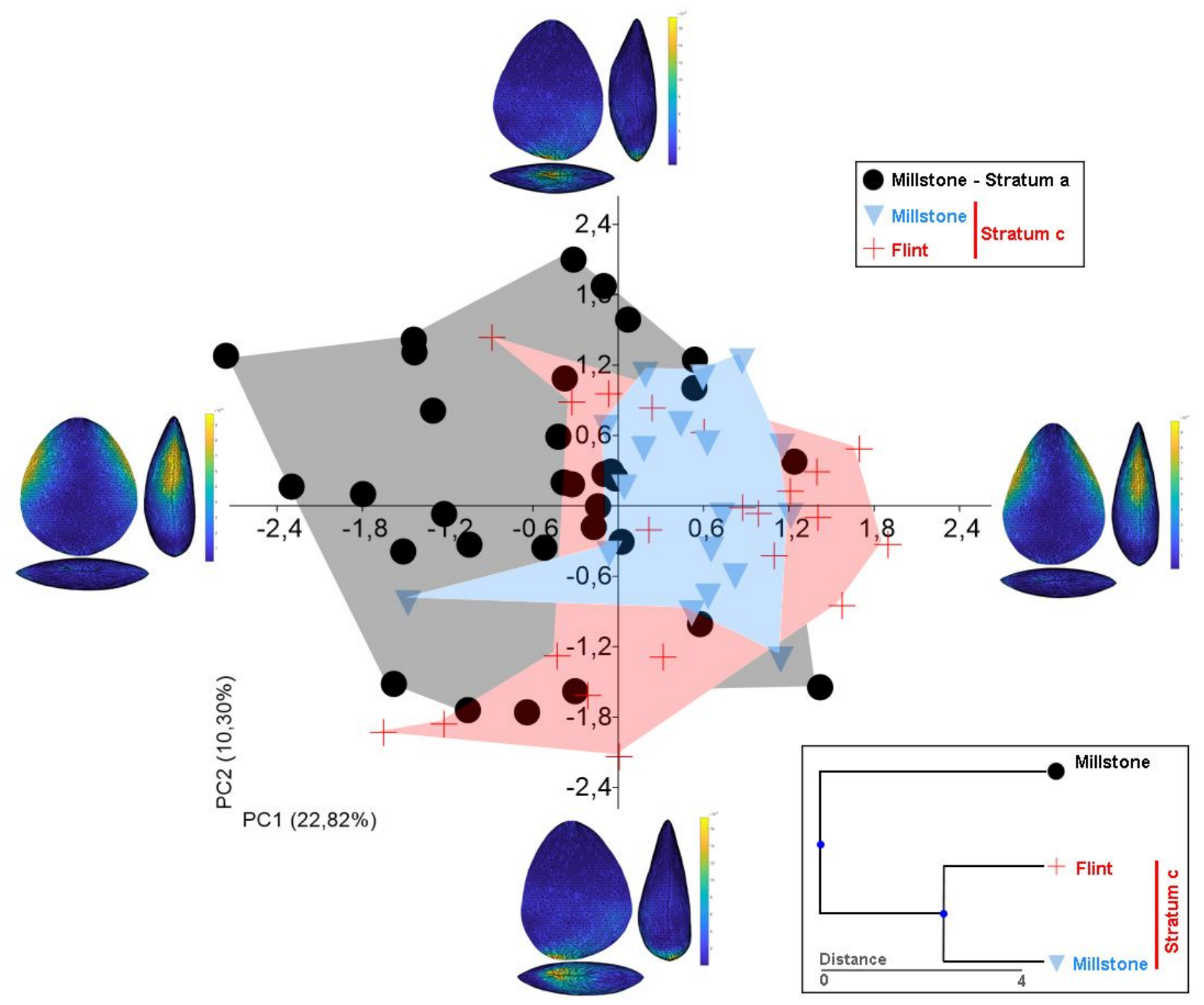

\section{Figure 7}

Principal component scatter plots of handaxes from La Noira, by strata and raw materials: millstone stratum a (black dots), millstone stratum c (blue triangles) and flint stratum c (red crosses). The geometric morphometric analysis was applied to 3D models, consisting of 5,000 semi-landmarks. It also includes convex hulls on each group to facilitate scatter plot visualization, and the warps' tool, representing morphology. Colour coding represents the most variable landmarks in shape trend described on positive and negatives scores of PC1 and PC2. Lower right-hand side; Cluster analysis and distances between the groups represented in PCA. 


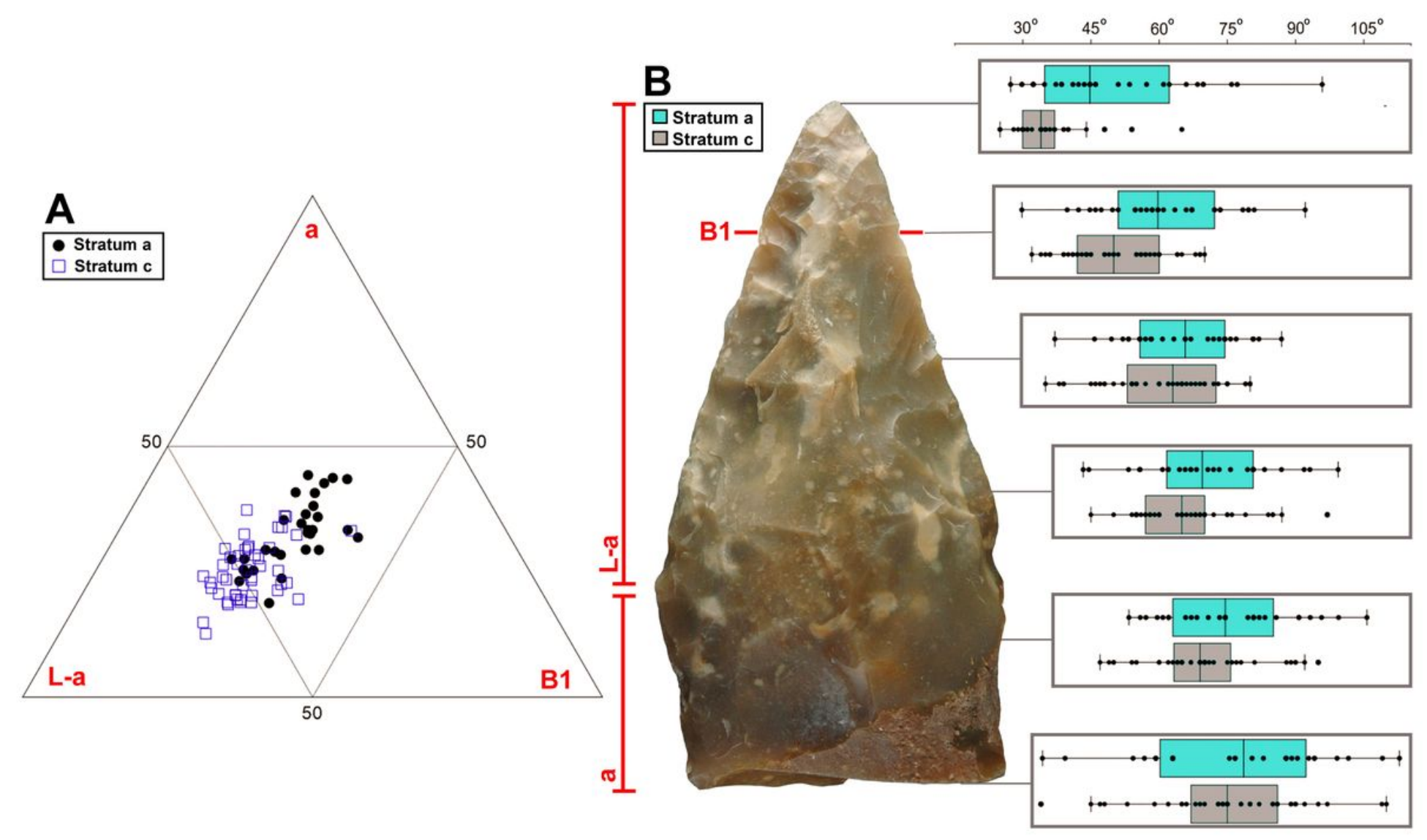

Figure 8

A) Ternary plot between Base Length (a), Distal Length (L-a) and Distal width (B1), from strata a and c. B) Angle distribution along the edges of tools from stratum a and stratum c of la Noira.

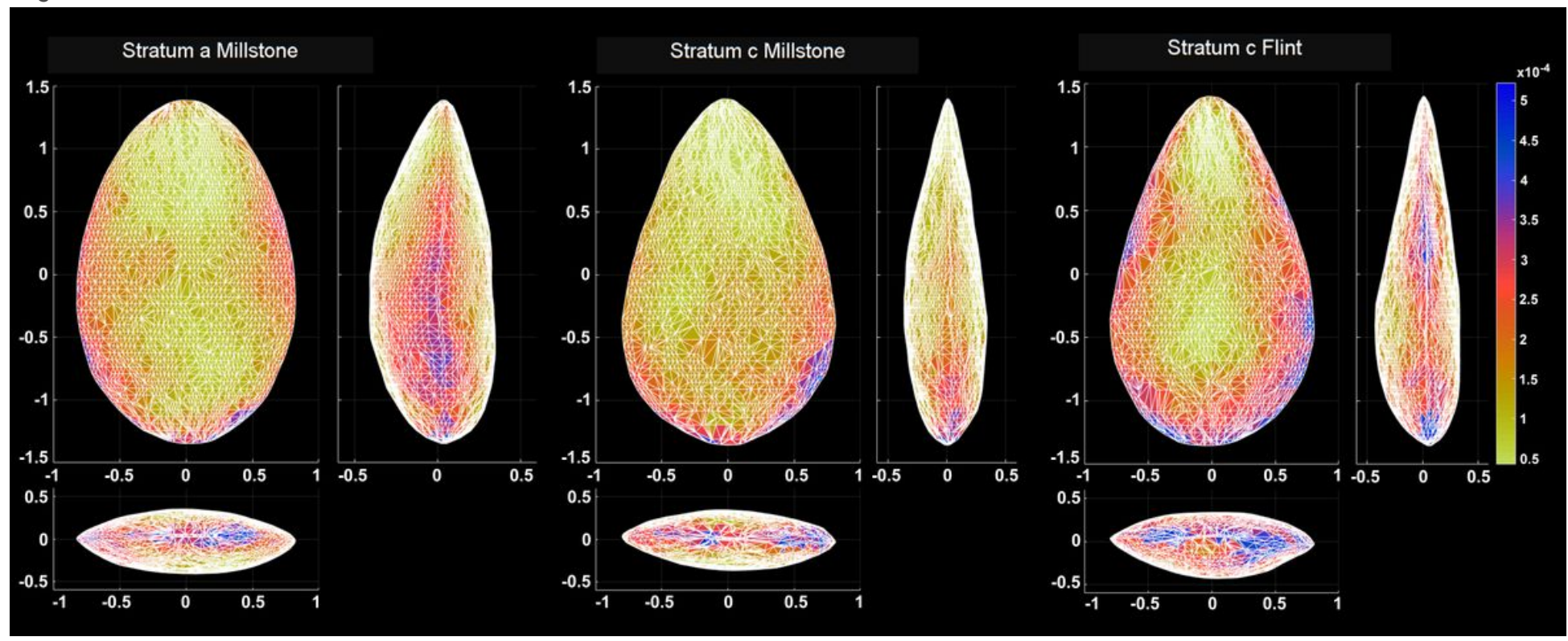

Figure 9

Mean shapes of LCTs from la Noira, stratum a and stratum $\mathrm{c}$ and the different raw materials (millstone and flint). Colour-coding represents the relative degree of variability of each individual semi-landmark reflecting the spatial distribution of variability in tools.

\section{Supplementary Files}


This is a list of supplementary files associated with this preprint. Click to download.

- Supplementarylnformation.docx 